Article

\title{
The Potential of Small Mountain River Systems for Paleoenvironmental Reconstructions in Drylands-An Example from the Binaloud Mountains in Northeastern Iran
}

\author{
Azra Khosravichenar ${ }^{1,2,3}$, Morteza Fattahi ${ }^{4} \oplus$, Hamideh Amini ${ }^{4}$ and Hans von Suchodoletz ${ }^{2, *}$ \\ 1 Department of Human Evolution, Max Planck Institute for Evolutionary Anthropology, D-04103 Leipzig, \\ Germany; azra_khosravichenar@eva.mpg.de \\ 2 Institute of Geography, Leipzig University, D-04103 Leipzig, Germany \\ 3 Department of Geography, Ferdowsi University of Mashhad, Mashhad IR-9177948974, Iran \\ 4 Institute of Geophysics, University of Tehran, Tehran IR-141556466, Iran; mfattahi@ut.ac.ir (M.F.); \\ hiamini@ut.ac.ir (H.A.) \\ * Correspondence: hans.von.suchodoletz@uni-leipzig.de; Tel.: +49-341-9732-969
}

Received: 2 September 2020; Accepted: 5 November 2020; Published: 9 November 2020

\begin{abstract}
Fluvial sediments are valuable paleoenvironmental archives of the Quaternary. Since besides environmental factors they are also affected by local tectonics or intrinsic processes, large instead of small catchments should be studied. In drylands covering ca. $45 \%$ of the global terrestrial surface large river systems are generally missing, and most river systems are small rivers originating from mountain ranges. Their sediments are potentially interesting paleoenvironmental archives, but are often affected by intensive tectonics. During this study, to obtain a robust regional paleoenvironmental signal a small river system in the southwestern Binaloud Mountains in semi-arid NE Iran was exemplarily studied with a combined approach that encompassed both alluvial fan and catchment. By using geomorphological mapping and numerical dating, fluvial aggradation followed by incision was independently identified in larger areas or in different parts of the river system ca. 95-88 ka, $40 \mathrm{ka}$, $20 \mathrm{ka}$, around/after the Pleistocene/Holocene transition and possibly ca. $2.6 \mathrm{ka}$. These could be linked with regional and over-regional paleoenvironmental data. Furthermore, large boulders on the alluvial fan suggest anthropogenic destabilisation of the catchment during the last decades. Despite strong local tectonics the fluvial dynamics was mostly controlled by paleoenvironmental changes and human activity. This indicates that despite their small size, such river systems form valuable paleoenvironmental archives in drylands where other archive types are largely missing.
\end{abstract}

Keywords: fluvial geomorphology; paleoenvironmental reconstruction; drylands; late Quaternary; tectonics; alluvial fans; Iran 


\section{Introduction}

Fluvial sediments are valuable archives of Quaternary landscape evolution and paleoenvironmental changes [1-11]. Dynamics and sedimentation patterns are directly or indirectly controlled by environmental and climatic factors, but also by local tectonics, base level changes, human activity and river-intrinsic effects [12-14]. To obtain robust paleoenvironmental information that is representative of a larger region, large catchments with sizes of several hundreds to thousands of square kilometers should be studied instead of small ones with sizes of just a few square kilometers. The reason is that the latter are very sensitive towards individual events that can be linked with local human or tectonic factors or river-intrinsic processes [14].

Due to the general absence of precipitation, large river systems with catchments of several hundreds to thousands of square kilometers are often missing in drylands that cover ca. $45 \%$ of the global land surface [15]. Furthermore, if they exist these are either exotic streams that originate from more humid regions and, therefore, mostly display the hydrological dynamics of the latter [16], or they are currently paleovalleys that originate from former more humid periods but are not sensitive to smaller-scale hydrological variations during drier phases [17]. Instead, most dryland river systems are small rivers with catchments of some square kilometers that originate from more humid mountain ranges. Their sediments are potentially interesting paleoenvironmental archives and also store smaller-scale regional paleoenvironmental variations. However, the transitions between mountain ranges and forelands where they are located generally show high tectonic activity [18]. Therefore, they were regularly affected by tectonic movements and seismic events during the late Quaternary. This could potentially have overprinted regional paleoenvironmental signals in their sediments [19].

During the last few decades, mostly alluvial fans of small river systems with catchments of some square kilometers (mountain-front alluvial fans) [20] were studied in different drylands for paleoenvironmental changes [20-24], and this is also true for eastern and northeastern Iran [19,25]. However, most studies in that region only encompassed the latest Pleistocene and Holocene, and numerous widely spaced fan systems were compared with each other to obtain robust regional paleoenvironmental information. Similar to other drylands, apart from singular playa and lake sediment records with often poor chronological resolution [26-29], and loess-paleosol sequences in the more humid northern region [30-35], other types of paleoenvironmental archives are widely missing here. Therefore, fluvial sediments of small river systems are potentially interesting regional paleoenvironmental archives.

During this study, we exemplarily investigated a small river system with a catchment of some square kilometers at the southwestern foothill of the Binaloud Mountain Range (BMR) in the drylands of northeastern Iran (Figure 1). Unlike most former investigations of such river systems, our study encompassed both the alluvial fan and uplifted terraces in the high mountain catchment, the latter representing older fluvial phases where the sediments were protected from subsequent fluvial erosion by their elevated topographic position. The goals were to (i) investigate whether such a combined approach yields more robust regional paleoenvironmental information and reaches further back in time compared with studies that exclusively focus on the alluvial fans, and (ii) contribute to the still largely unknown paleoenvironmental history of the drylands of eastern and northeastern Iran. 


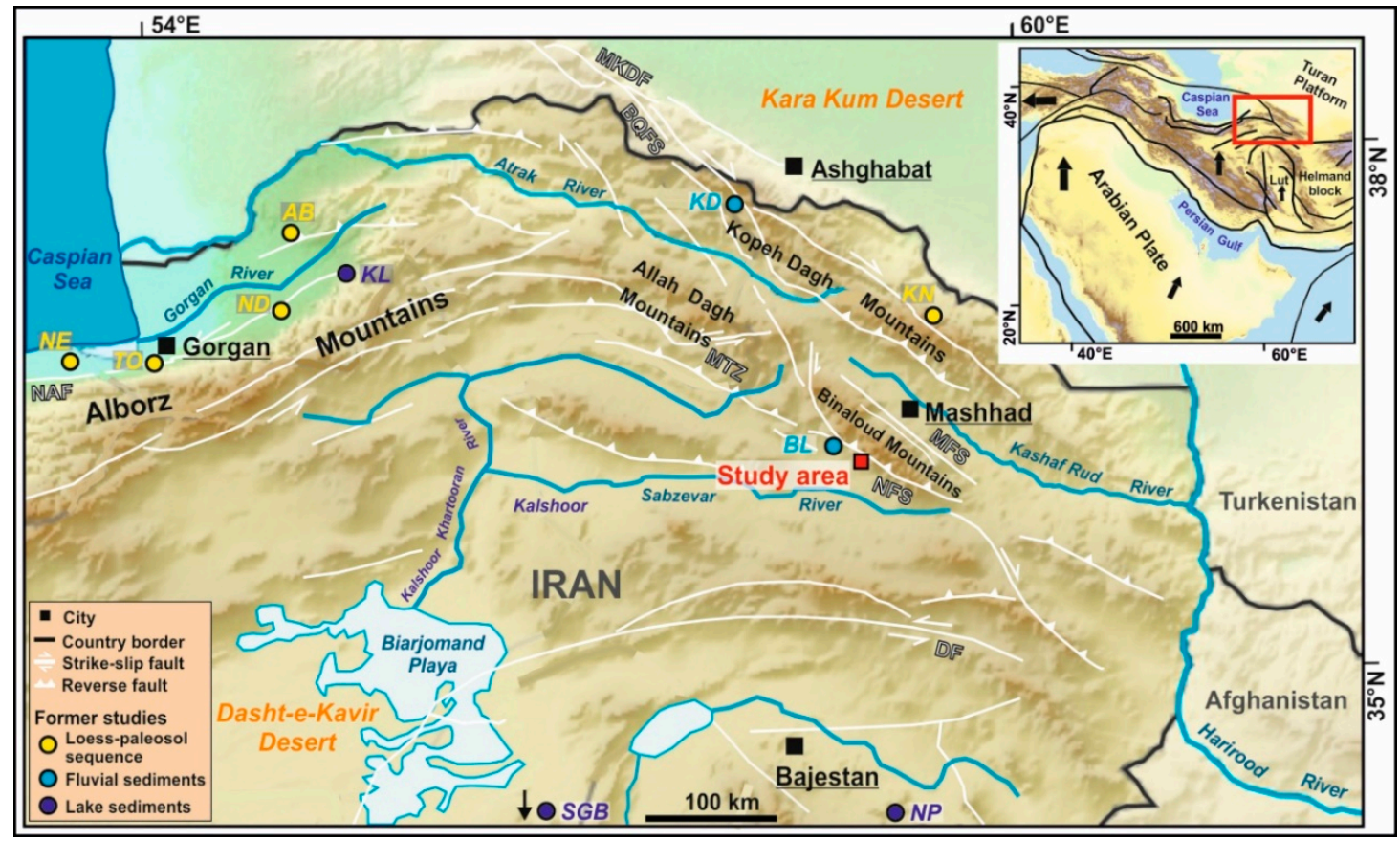

Figure 1. Overview of the study region in northeastern Iran with the regional tectonic setting (taken from [36]). The study area in the southwestern Binaloud Mountains is marked with a red rectangle, and the sites of former paleoenvironmental studies with coloured circles (Loess-paleosol sequences: NE = Neka, TO = Toshan, ND = Now Deh, AB = Agh Band [32-34], KN = Kalat-e-Naderi [31]; Fluvial sediments: KD = Kopeh Dagh [37], BL = Binaloud Mountains [38]; Lake sediments: NP = Nimbluk Plain [27], SGB = South Golbaf Basin [26], KL = Kongor Lake [39]). BQFS = Bakharden-Quchan Fault System, DF = Doruneh Fault, MTZ = Meshkan Transfer Zone, MFS = Mashhad Fault System, MKDF = Main Kopeh Dagh Fault, NAF = North Alborz Fault, NFS = Neyshabour Fault System. The study region in northeastern Iran in a larger regional tectonic context [36]. Map sources: Digital Elevation Model GTOPO30 (https://earthexplorer.usgs.gov) and Digital Elevation Model ALOS PALSAR (https://vertex.daac.asf.alaska.edu).

\section{Study Region and Studied River System}

\subsection{Study Region}

Our study was carried out at the southwestern margin of the $130 \mathrm{~km}$ long northwest-southeast directed BMR in northeastern Iran (Figure 1). The BMR was formed since the Paleo-Tethys closure due to the collision of the Arabian with the Eurasian plate (pre-Late Triassic) [36], and reaches up to $3211 \mathrm{~m}$ a.s.l. Its southwestern margin is characterized by numerous mountain-front alluvial fans (Figure 2a).

The BMR is tectonically active, with shortening of one to several $\mathrm{mm}$ per year across its southwestern margin [36,38], potentially accompanied by a similar amount of right-lateral strike-slip [36]. This is, for example, expressed by the Neyshabour Fault System $(90 \mathrm{~km})$ that has developed along its southwestern margin. This fault system encompasses several fault strands/zones such as the Barfriz fault zone, Doro and Kharve Faults [40] (Figures 1 and 2a). The current regional climate is semi-arid, with ca. $185 \mathrm{~mm}$ annual precipitation and a mean annual temperature of ca. $12.8^{\circ} \mathrm{C}$ (station Neyshabour; https://globalweather.tamu.edu; location see Figure 2a). Most precipitation falls during winter and spring between November and May (Figure 2b) linked with westerly disturbances [41]. The region belongs to the Irano-Turanian phytogeographical region [42]. Sedentary regional human activity is documented since the Late Bronze Age ca. 4 ka [43-45]. 


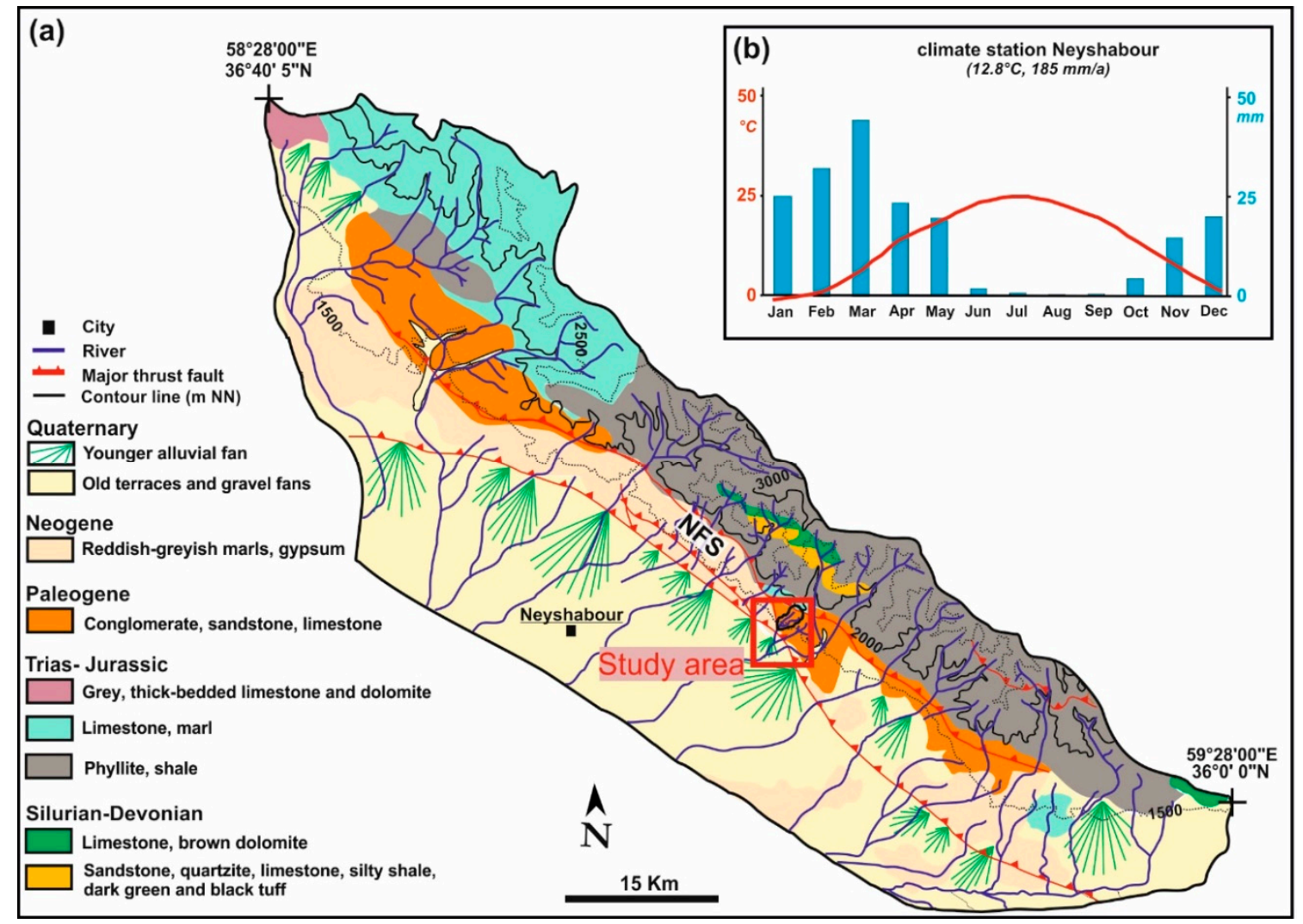

Figure 2. (a) Geological and geomorphological map of the southwestern margin of the Binaloud Mountain Range. The studied river system is marked with a red rectangle. The geology is based on the geological map 1: 250,000 sheet Mashhad [46], and the alluvial fans were mapped using Google Earth (2019). NFS = Neyshabour Fault System. (b) Climate diagram of the station Neyshabour (https://globalweather.tamu.edu) (location see Figure 2a).

\subsection{Studied River System}

Our study was carried out in the Kalshur river system. With a size of ca. $3.3 \mathrm{~km}^{2}$ it represents one of the smallest catchments at the southwestern margin of the BMR (Figure 2a). We selected this river system for two reasons: (i) we wanted to evaluate whether our combined approach also works in very small catchments, and (ii) the small size of the catchment allowed detailed field mapping by walking, resulting in a detailed and comprehensive understanding of the local geomorphology. The present-day alluvial fan with a recognizable minimal size of ca. $0.66 \mathrm{~km}^{2}$ extends between ca. $1380-1350 \mathrm{~m}$ a.s.l. at the transition of the BMR towards its southwestern foreland, and the catchment in the southwestern BMR reaches up to ca. $2100 \mathrm{~m}$ a.s.l. (Figure 2a). The river system forms part of the hydrological basin of the Boojmehran River, a tributary of the Kalshoor River that flows into the Biarjomand Playa in the Dasht-e-Kavir Desert (Figure 1). 
The Neyshabour Fault System crosses the Kalshur catchment from northwest to southeast with two main fault zones: these are the Barfriz Fault in the northeast and the larger Buzhan Fault zone in the southwest (Figure 3). The former is an active oblique-slip reverse fault, and the latter is characterized by several parallel fault segments with currently both reverse and right-lateral oblique-slip faulting. The Buzhan Fault zone forms the currently active frontal fault zone of the BMR foothills [40]. Due to the small-scale local tectonic pattern the catchment geology is very diverse: Devonian metamorphites, limestones, black clay shales and sandstones as well as Triassic shales, phyllites and metasandstones form the upper part, and Eocene to Oligocene partly gypsiferous marls, siltstones, sandstones, conglomerates, black clay shales and green tuffs the central and lower part. The river system is composed of two main rivers, whereof the eastern one has a larger catchment and, therefore, a larger discharge. Along both main rivers several fluvial terrace levels are developed, extending downstream up to the fan apex (Figure 3). The current river bed mostly consists of pebbly to sandy grain sizes with singular large boulders $>1 \mathrm{~m}$. The discharge regime is periodic, with maximal discharge due to maximal precipitation and concomitant snowmelt during late winter, whereas no discharge occurs during the dry summer season [47]. The current vegetation of the catchment is formed by semiarid steppes with singular trees at protected positions. Since human influence is characterized by seasonal grazing with sheeps and goats, the current vegetation probably shows a degradation state of the potential natural vegetation.

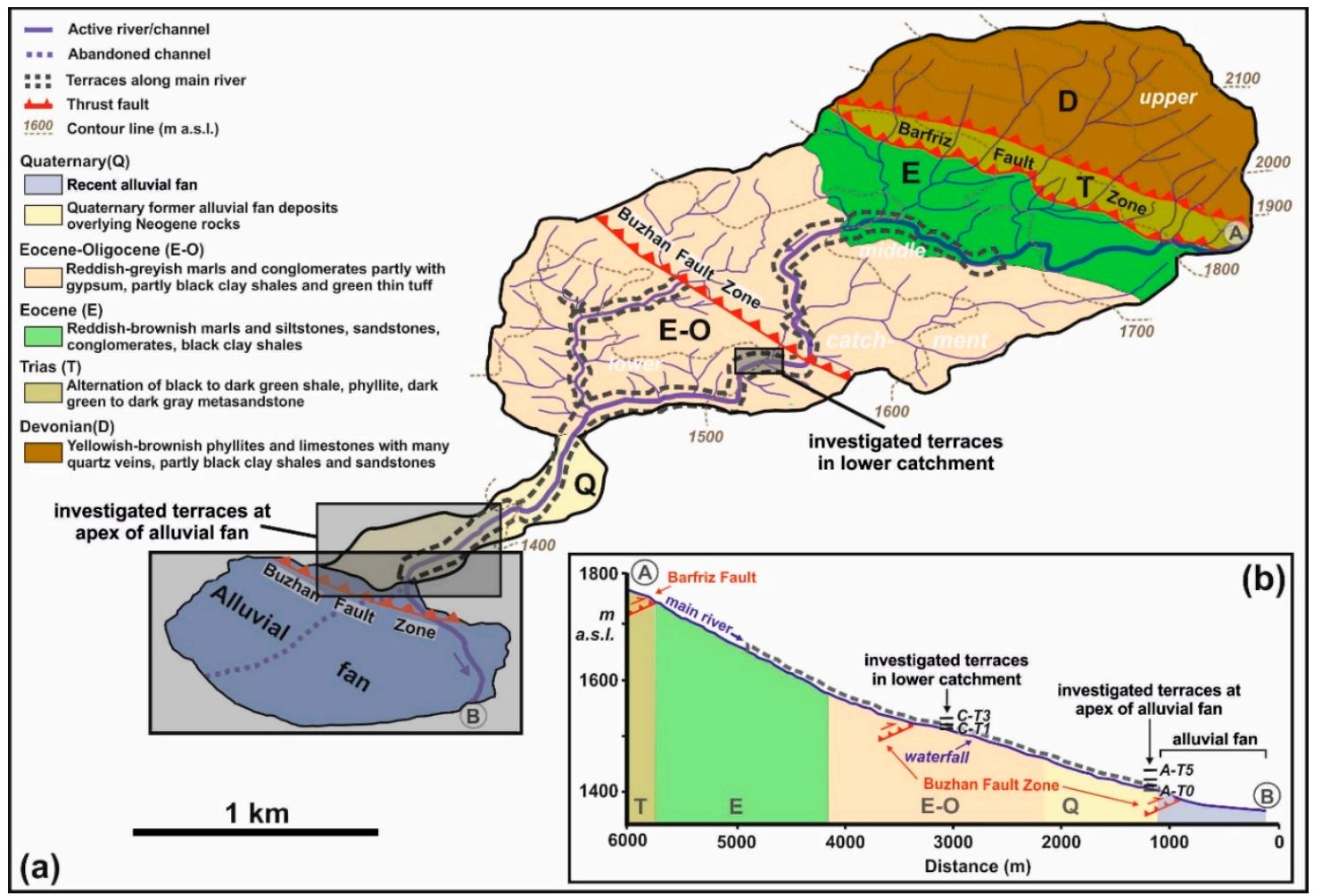

Figure 3. (a) Geological and geomorphological map of the studied Kalshur river system. The three studied sites are marked with grey rectangles. (b) Altitudinal profile along the main eastern river in the catchment and the currently active southeastern river channel on the present-day alluvial fan (from A to B). The profile was created based on measurements with the barometric altimeter of a hand-held Global Positioning System (GPS) device. The geology of the figures is based on the geological map 1:25,000 sheet Kharv [48], but was modified according to own field observations. The locations of main faults were provided by Esmail Shabanian (oral communication 2020). The distribution of terrace levels along the river courses is based on our own field observations. 


\section{Methods}

\subsection{Geomorphological Mapping}

Going upstream from the apex of the present-day alluvial fan, we mapped the distribution of fluvial terrace levels along the two main rivers. At two sites, one at the main eastern river in the lower catchment $\left(36^{\circ} 11^{\prime} 13.1^{\prime \prime} \mathrm{N}, 59^{\circ} 00^{\prime} 52.7^{\prime \prime} \mathrm{E}\right)$ and one at the fan apex $\left(36^{\circ} 10^{\prime} 37.9^{\prime \prime} \mathrm{N}, 59^{\circ} 00^{\prime} 05.9^{\prime \prime} \mathrm{E}\right)$, geomorphology and sedimentology of the terrace levels were mapped in detail (Figure 3a). Their elevations above the current river course were determined with a precision of $\pm 1 \mathrm{~m}$ using the barometric altimeter of a hand-held Global Positioning System (GPS). Furthermore, using this barometric altimeter we mapped the altitudes of a river longitudinal profile along the main eastern river and along the currently active river course on the present-day alluvial fan (Figure 3b). Furthermore, we checked the upper catchment for visible traces of Quaternary glaciations.

At the present-day alluvial fan, supported by satellite images (Google Earth 2019) we used relative altitudes and geomorphic features indicating incision and denudation after initial fluvial aggradation to map different surface generations in the field. Furthermore, to identify varying geomorphic activity in different parts of the catchment we mapped all boulders on the fan surface with diameters $>1 \mathrm{~m}$. To do so, we classified them according to size (1-2 $\mathrm{m}$ and $\geq 2 \mathrm{~m}$ ) and lithology (dark-coloured metamorphites, sand-/siltstones/other metamorphites, gypsum, conglomerates), and measured their geographic position using a hand-held GPS. Finally, their distribution was drawn using ArcGIS 10.6.

\subsection{Luminescence Dating}

To date the fluvial sediments using infrared stimulated luminescence (IRSL) of feldspars, three samples were taken from the studied fluvial terrace levels at the main eastern river in the lower catchment, and five samples from fluvial terrace levels at the fan apex. According to the field stratigraphy the sampling locations were selected at sites that were obviously not influenced by post-sedimentary reworking and relocation processes and should, therefore, represent the timing of terrace aggradation. The samples were taken from natural outcrops during night and directly packed into light-proof plastic bags. To only sample material that was not influenced by sunlight, we removed the outer $20 \mathrm{~cm}$ of the material right before sampling. Furthermore, we collected six samples belonging to different phases of the present-day alluvial fan from artificially dug pits during daylight under a lightproof tarpaulin fabric, by hammering stainless steel tubes horizontally into the freshly cut vertical sections. Also here, according to our geomorphological observations, the sampling sites were selected at places that were obviously not affected by post-sedimentary reworking or younger fluvial processes. Therefore, these samples should also represent the timing of primary sediment aggradation. If possible, more sandy lenses within the mostly gravelly material were sampled. In parallel with the luminescence samples, ca. $500 \mathrm{~g}$ of material were taken from the same positions during daylight for dose rate determination. The sedimentological properties of all luminescence sampling sites are described in Table S1. 
Luminescence dating was performed in the luminescence laboratory of the Institute of Geophysics of the University of Tehran (Iran). Pre-tests showed a very low quantity of quartz with very low luminescence signal intensities and a low ratio of grains giving any signal at all. Therefore, potassium feldspars were used. All samples were prepared under subdued red light following the procedure described in $[26,49]$. All measurements were performed using a Lexsygsmart-Automated TL/OSL Reader (Freiberg Instruments, Freiberg, Germany), equipped with a ${ }^{90} \mathrm{Sr} /{ }^{90} \mathrm{Y} \beta$-source 3203 (activity $1.85 \mathrm{GBq}$ and a maximum energy of $2.27 \mathrm{MeV} \approx 6 \mathrm{~Gy} / \mathrm{min}$ ) and an infrared laser diode $(850 \mathrm{~nm})$ for stimulation. The blue emission of feldspar was measured using the filter combination BG $39+$ HC 414/46.

First, the post-IRSL (pIRIR) protocol [50] (Table S2) was applied with the standard acceptance criteria. To check whether a given lab dose could be recovered by the applied protocol, prior to the De measurements dose recovery preheat plateau tests were performed. The lab dose was successfully recovered by the IRSL50 ${ }^{\circ} \mathrm{C}$ signal, whereas it could not be recovered by the IRSL $290{ }^{\circ} \mathrm{C}$ signal (Figure S1). Anomalous fading of the feldspar grains was assessed using the same protocols (Table S2), and exemplary results are shown in Figure S3. There was no fading for the IRSL $290{ }^{\circ} \mathrm{C}$ signal, and surprisingly also the IRSL $50{ }^{\circ} \mathrm{C}$ signal did not show any fading. The reason for this is under investigation. To decrease the machine time, the single-aliquot regeneration (SAR) protocol for feldspars at $50{ }^{\circ} \mathrm{C}$ [49] (Table S3) was employed for De determination. The preheat and cut heat of $320^{\circ} \mathrm{C}$ (heating rate $5^{\circ} \mathrm{C} / \mathrm{s}$ ) successfully recovered the laboratory dose. The equivalent doses (De) of up to 40 aliquots per sample were measured. Given that no significant incomplete bleaching was detected, the final De's were calculated using the central age model (CAM). Decay curve, growth curve fitting and De distribution of exemplary sample A5-L are shown in Figure S2. All samples revealed no significant anomalous fading. Given doses and delay times of exemplary samples C-T2-L and A5-L are shown in Table S4, and plots of the fading tests for these samples in Figure S3.

The procedure described in $[26,49]$ was used for dose rate determination. The concentrations of the radioactive elements $\mathrm{U}$, Th and K were measured using ICP-MS (Baspar Payesh Pars Lab Mashhad/Iran, and Novin Shimyar Chemical Co. lab, Tehran, Iran, respectively) (Table 1). The samples showed very low water contents of maximal $5 \%$. Furthermore, especially in the present-day alluvial fan their matrices are very sandy with very low water retention capacities, and the fluvial terrace levels were incised relatively shortly after their formation leading to their desiccation during most of the burial period. Therefore, a water content of $6 \pm 4 \%$ seems realistic for the burial periods of the samples and was taken for dose rate calculation. Table 1 shows the values used to determine the annual dose rates. 
Table 1. Parameters and results of the luminescence datings (feldspar infrared stimulated luminescence (IRSL) at $50^{\circ} \mathrm{C}$ ).

\begin{tabular}{|c|c|c|c|c|c|c|c|c|c|c|c|}
\hline Sample ID & $\begin{array}{c}\text { Taken from } \\
\text { Sediment Unit }\end{array}$ & $\begin{array}{c}\text { Geographic Coordinates and } \\
\text { Approximate Altitude } \\
\text { (m a.s.l.) }\end{array}$ & De (Gy) & Depth Below Surface (m) & Water $(\%)$ & $\mathrm{K}(\%)$ & $\mathrm{U}(\mathrm{ppm})$ & Th (ppm) & $\begin{array}{c}\text { Cosmic Dose Rate } \\
\text { (Gy/ka) }\end{array}$ & $\begin{array}{l}\text { Total Dose Rate } \\
\text { (Gy/ka) }\end{array}$ & Age (ka) \\
\hline \multicolumn{12}{|c|}{ Samples taken from Terraces in Lower Catchment } \\
\hline $\mathrm{C}-\mathrm{T} 1-\mathrm{L}^{2}$ & Terrace C-T1 & $\begin{array}{c}36^{\circ} 11^{\prime} 13.1^{\prime \prime} \mathrm{N}, 59^{\circ} 00^{\prime} 52.7^{\prime \prime} \mathrm{E} \\
1520 \mathrm{~m}\end{array}$ & $7.0 \pm 1.1$ & $0.8 \pm 0.08$ & $6 \pm 4$ & $1.80 \pm 0.09$ & $1.0 \pm 0.05$ & $1.6 \pm 0.08$ & $0.232 \pm 0.028$ & $2.67 \pm 0.12$ & $2.63 \pm 0.4$ \\
\hline $\mathrm{C}-\mathrm{T} 2-\mathrm{L}^{2}$ & Terrace C-T2 & $\begin{array}{c}36^{\circ} 11^{\prime} 13.1^{\prime \prime}{ }^{\prime} \mathrm{N}, 59^{\circ} 00^{\prime} 52.7^{\prime \prime} \mathrm{E} \\
1530 \mathrm{~m}\end{array}$ & $41.0 \pm 6.3$ & $1.25 \pm 0.13^{1}$ & $6 \pm 4$ & $1.06 \pm 0.05$ & $1.0 \pm 0.05$ & $0.5 \pm 0.03$ & $0.218 \pm 0.027$ & $1.90 \pm 0.07$ & $21.57 \pm 3.4$ \\
\hline $\mathrm{C}-\mathrm{T} 3-\mathrm{L}^{2}$ & Terrace C-T3 & $\begin{array}{c}36^{\circ} 11^{\prime} 13.1^{\prime \prime} \mathrm{N}, 59^{\circ} 00^{\prime} 52.7^{\prime \prime} \mathrm{E} \\
1540 \mathrm{~m}\end{array}$ & $81.0 \pm 12.4$ & $4.0 \pm 0.4^{1}$ & $6 \pm 4$ & $1.17 \pm 0.06$ & $1.1 \pm 0.06$ & $0.8 \pm 0.04$ & $0.152 \pm 0.019$ & $1.98 \pm 0.08$ & $41.00 \pm 6.5$ \\
\hline \multicolumn{12}{|c|}{ Samples taken from Terraces at Apex of Present-day Alluvial Fan } \\
\hline A-T1-L $L^{3}$ & Terrace A-T1 & $\begin{array}{c}36^{\circ} 10^{\prime} 37.9^{\prime \prime} \mathrm{N}, 59^{\circ} 00^{\prime} 05.9^{\prime \prime} \mathrm{E} \\
1400 \mathrm{~m}\end{array}$ & $27.2 \pm 1.9$ & $0.33 \pm 0.03$ & $6 \pm 4$ & $2.47 \pm 0.12$ & $2.0 \pm 0.1$ & $8.12 \pm 0.41$ & $0.276 \pm 0.026$ & $3.99 \pm 0.16$ & $6.83 \pm 0.6$ \\
\hline A-T2L-L ${ }^{3}$ & $\begin{array}{l}\text { Terrace A-T2 (left } \\
\text { bank of the } \\
\text { Kalshur River) }\end{array}$ & $\begin{array}{c}36^{\circ} 10^{\prime} 37.9^{\prime \prime} \mathrm{N}, 59^{\circ} 00^{\prime} 05.9^{\prime \prime} \mathrm{E} \\
1400 \mathrm{~m}\end{array}$ & $73.2 \pm 6.0$ & $0.33 \pm 0.03$ & $6 \pm 4$ & $2.46 \pm 0.12$ & $1.7 \pm 0.09$ & $6.81 \pm 0.34$ & $0.262 \pm 0.026$ & $3.81 \pm 0.16$ & $19.23 \pm 1.9$ \\
\hline A-T2R-L $\mathrm{L}^{3}$ & $\begin{array}{l}\text { Terrace A-T2 (right } \\
\text { bank of the } \\
\text { Kalshur River) }\end{array}$ & $\begin{array}{c}36^{\circ} 10^{\prime} 37.9^{\prime \prime} \mathrm{N}, 59^{\circ} 00^{\prime} 05.9^{\prime \prime} \mathrm{E} \\
1400 \mathrm{~m}\end{array}$ & $160.5 \pm 16.3$ & $\begin{array}{c}0.33 \pm 0.03 \\
\text { (today covered by } \\
\text { anthropogenic road deposits) }\end{array}$ & $6 \pm 4$ & $2.71 \pm 0.14$ & $1.5 \pm 0.08$ & $5.64 \pm 0.28$ & $0.255 \pm 0.026$ & $3.90 \pm 0.17$ & $41.11 \pm 4.7$ \\
\hline A-T3-L $\mathrm{L}^{3}$ & Terrace A-T3 & $\begin{array}{c}36^{\circ} 10^{\prime} 37.9^{\prime \prime} \mathrm{N}, 59^{\circ} 00^{\prime} 05.9^{\prime \prime} \mathrm{E} \\
1410 \mathrm{~m}\end{array}$ & $232.1 \pm 10.9$ & $0.33 \pm 0.03$ & $6 \pm 4$ & $1.46 \pm 0.07$ & $1.3 \pm 0.07$ & $4.5 \pm 0.23$ & $0.262 \pm 0.026$ & $2.64 \pm 0.10$ & $87.77 \pm 5.8$ \\
\hline A-T4- $\mathrm{L}^{2}$ & Terrace A-T4 & $\begin{array}{c}36^{\circ} 10^{\prime} 37.9^{\prime \prime} \mathrm{N}, 59^{\circ} 00^{\prime} 05.9^{\prime \prime} \mathrm{E} \\
1410 \mathrm{~m}\end{array}$ & $193.0 \pm 29.5$ & $2.75 \pm 0.28^{1}$ & $6 \pm 4$ & $1.20 \pm 0.06$ & $0.8 \pm 0.04$ & $0.7 \pm 0.04$ & $0.179 \pm 0.022$ & $2.03 \pm 0.08$ & $94.88 \pm 15.2$ \\
\hline \multicolumn{12}{|c|}{ Samples taken from Present-day Alluvial Fan } \\
\hline $\mathrm{A} 1-\mathrm{L}^{2}$ & Generation II & $\begin{array}{c}36^{\circ} 10^{\prime} 33.9^{\prime \prime} \mathrm{N}, 58^{\circ} 59^{\prime} 58.1^{\prime \prime} \mathrm{E} \\
1380 \mathrm{~m}\end{array}$ & $12.5 \pm 1.91$ & $0.3 \pm 0.05$ & $6 \pm 4$ & $0.15 \pm 0.008$ & $0.5 \pm 0.025$ & $0.3 \pm 0.015$ & $0.248 \pm 0.045$ & $0.96 \pm 0.05$ & $12.96 \pm 2.1$ \\
\hline $\mathrm{A} 2-\mathrm{L}^{3}$ & Generation II & $\begin{array}{c}36^{\circ} 10^{\prime} 32.6^{\prime \prime} \mathrm{N}, 58^{\circ} 59^{\prime} 58.50^{\prime \prime} \mathrm{E} \\
1380 \mathrm{~m}\end{array}$ & $50.9 \pm 4.5$ & $0.33 \pm 0.03$ & $6 \pm 4$ & $2.68 \pm 0.13$ & $1.6 \pm 0.08$ & $6.25 \pm 0.31$ & $0.247 \pm 0.025$ & $3.94 \pm 0.17$ & $12.93 \pm 1.3$ \\
\hline A4- $\mathrm{L}^{3}$ & Generation I & $\begin{array}{c}36^{\circ} 10^{\prime} 29.10^{\prime \prime} \mathrm{N}, \\
59^{\circ} 0^{\prime} 0.55^{\prime \prime} \mathrm{E} \\
1380 \mathrm{~m} \\
\end{array}$ & $54.4 \pm 6.0$ & $0.33 \pm 0.03$ & $6 \pm 4$ & $2.72 \pm 0.14$ & $1.7 \pm 0.09$ & $7.58 \pm 0.25$ & $0.247 \pm 0.025$ & $4.09 \pm 0.17$ & $13.32 \pm 1.6$ \\
\hline A5- $\mathrm{L}^{3}$ & Generation III & $\begin{array}{c}36^{\circ} 10^{\prime} 27.80^{\prime \prime} \mathrm{N}, \\
59^{\circ} 0^{\prime} 4.80^{\prime \prime} \mathrm{E} \\
1380 \mathrm{~m} \\
\end{array}$ & $43.2 \pm 2.1$ & $0.33 \pm 0.03$ & $6 \pm 4$ & $2.60 \pm 0.13$ & $1.8 \pm 0.09$ & $8.9 \pm 0.45$ & $0.247 \pm 0.025$ & $4.08 \pm 0.17$ & $10.58 \pm 0.7$ \\
\hline $\mathrm{A} 7-\mathrm{L}^{3}$ & Generation IV & $\begin{array}{c}36^{\circ} 10^{\prime} 27.60^{\prime \prime} \mathrm{N}, \\
59^{\circ} 0^{\prime} 10.10^{\prime \prime} \mathrm{E}, \\
1370 \mathrm{~m} \\
\end{array}$ & $17.8 \pm 1.7$ & $0.33 \pm 0.03$ & $6 \pm 4$ & $2.37 \pm 0.12$ & $1.9 \pm 0.10$ & $8.63 \pm 0.43$ & $0.247 \pm 0.025$ & $3.88 \pm 0.15$ & $4.59 \pm 0.5$ \\
\hline A8- $\mathrm{L}^{3}$ & Generation IV & $\begin{array}{l}36^{\circ} 10^{\prime} 28.70^{\prime \prime} \mathrm{N}, \\
59^{\circ} 0^{\prime} 13.10^{\prime \prime} \mathrm{E} \\
1370 \mathrm{~m}\end{array}$ & $29.5 \pm 2.6$ & $0.33 \pm 0.03$ & $6 \pm 4$ & $2.45 \pm 0.12$ & $1.7 \pm 0.09$ & $4.78 \pm 0.24$ & $0.247 \pm 0.025$ & $3.65 \pm 0.16$ & $8.07 \pm 0.8$ \\
\hline
\end{tabular}

${ }^{1}$ In cases where samples were taken from outcrops of strongly eroded terraces, the mean value between the current and the former maximal depth below the surface was taken. ${ }^{2}$ Dose rate determination (contents of U, Th and K) was carried out in the Novin Shimyar Chemical Co. Lab, Tehran (Iran). ${ }^{3}$ Dose rate determination (contents of U, Th and K) was carried out in the Baspar Payesh Pars Lab in Mashhad (Iran). 


\section{Results}

\subsection{Geomorphological Mapping}

\subsubsection{Catchment}

Along the two main rivers in the lower and central catchment, a staircase of three well-developed fluvial fill terrace levels with altitudes up to $>20 \mathrm{~m}$ above the current river beds was found (Figure 3). These constitute the remains of sediments that filled the valley bottoms during different periods in the past (from bottom to top named C-T1-C-T3). At some locations also small remains of a younger level C-T0 that was inset in level C-T1 were observed. Furthermore, at some places along the main eastern river in the lower catchment singular boulders of Devonian dark-coloured metamorphites were found at the slopes above terrace level C-T3. The Eocene to Oligoence geology of the lower and central catchment does not contain such metamorphites, but similar boulders also occur in the well-developed terrace fills. Therefore, these were obviously brought by the river from the Devonian bedrocks in the upper catchment (Figure 3), indicating former higher terrace levels that are largely eroded today. Thus, the terrace staircase in the catchment is formed by at least five different levels. The properties of the three well-developed levels C-T1 to C-T3 at the main eastern river that were studied in detail (Figure 4, location see Figure 3) are given in Table 2.

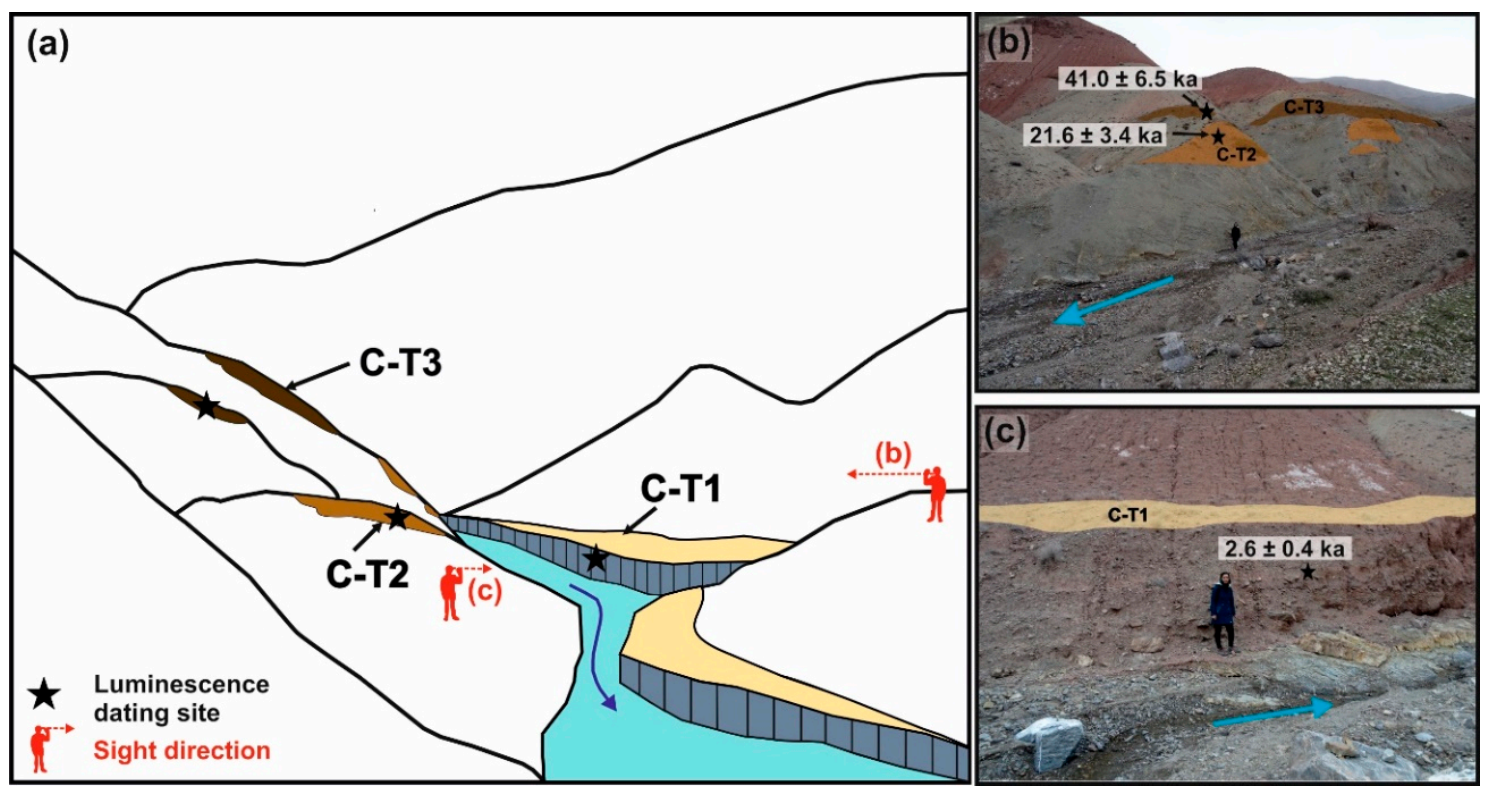

Figure 4. The studied terrace levels C-T1-C-T3 at the main eastern river in the lower catchment with luminescence ages (location in the river system please see Figure 3) (a) Sketch of the terrace levels seen upstream. (b) Terrace levels C-T2 and C-T3 at the right bank of the river. (c) Terrace level C-T1 at the left bank of the river. Please note the large boulders in the current river bed.

No traces of former Quaternary glaciations such as U-shaped valleys, moraines or cirques were observed in the catchment. 
Table 2. Table of terrace properties.

\begin{tabular}{|c|c|c|c|c|c|c|}
\hline Terrace & $\begin{array}{l}\text { Upper Height above } \\
\text { Current River Bed (m) }\end{array}$ & $\begin{array}{l}\text { Lower Height of Sediment Fill } \\
\text { above Current River Bed (m) }\end{array}$ & $\begin{array}{c}\text { Thickness of } \\
\text { Sediment Fill (m) }\end{array}$ & Material Properties & Approximate Width (m) & $\begin{array}{l}\text { Bedrock Incision after Aggradation, } \\
\text { i.e., During Terrace Formation (m) }\end{array}$ \\
\hline \multicolumn{7}{|c|}{ Lower Catchment } \\
\hline C-T1 & 2 & 0 & 2 (min value) & gravelly-sandy & 50 & 0 \\
\hline C-T2 & 10 & 6 & 4 & $\begin{array}{l}\text { Lower part gravelly-sandy, } \\
\text { upper part gravelly-loamy }\end{array}$ & $100-150$ & 6 (min value) \\
\hline C-T3 & 21 & 11 & 10 & $\begin{array}{l}\text { Lower part gravelly-sandy, } \\
\text { upper part gravelly-loamy }\end{array}$ & $150-200$ & 5 \\
\hline \multicolumn{7}{|c|}{ Apex of Present-day Alluvial Fan } \\
\hline A-T0 & $1-1.5$ & 0 & $1-1.5$ (min value) & gravelly-sandy & $20-100$ & 0 \\
\hline A-T1 & $2-3$ & 1 & $1-2$ & gravelly-sandy & $40-105$ & 1 (min value) \\
\hline A-T2 & 5 & $1-2$ & $3-4$ & gravelly-sandy & $70-105$ & $0-1$ \\
\hline A-T3 & 11 & 7 & 4 & gravelly-sandy & $90-115$ & $5-6$ \\
\hline A-T4 & 21 & 17 & 4 & gravelly-sandy & 130 & 10 \\
\hline A-T5 & 39 & 20 & 19 & gravelly-sandy & $\begin{array}{l}\text { Former continuous } \\
\text { surface }\end{array}$ & 3 \\
\hline
\end{tabular}




\subsubsection{Apex of the Present-Day Alluvial Fan}

At the fan apex, a staircase of six well-developed fluvial fill terrace levels with maximal elevations $>40 \mathrm{~m}$ above the current river bed was mapped (named from bottom to top A-T0-A-T5; Figure 5, location see Figure 3). Unfortunately, due to longitudinal interruptions of the terrace levels and their partial merging these could not be followed over longer distances upstream. Therefore, no direct correlation between these terrace levels and those in the catchment was possible. Whereas the uppermost terrace A-T5 constitutes the highest surface level and must formerly have formed a large continuous surface, the younger terrace levels A-T4 to A-T0 were aggraded in the Kalshur valley that had formed after incision of A-T5. With decreasing elevation levels A-T4 to A-T2 systematically extend further into the foreland, and A-T2 is limited by a gentle scarp of ca. 1-1.5 $\mathrm{m}$ from the surface of the present-day alluvial fan (Figure 5a).

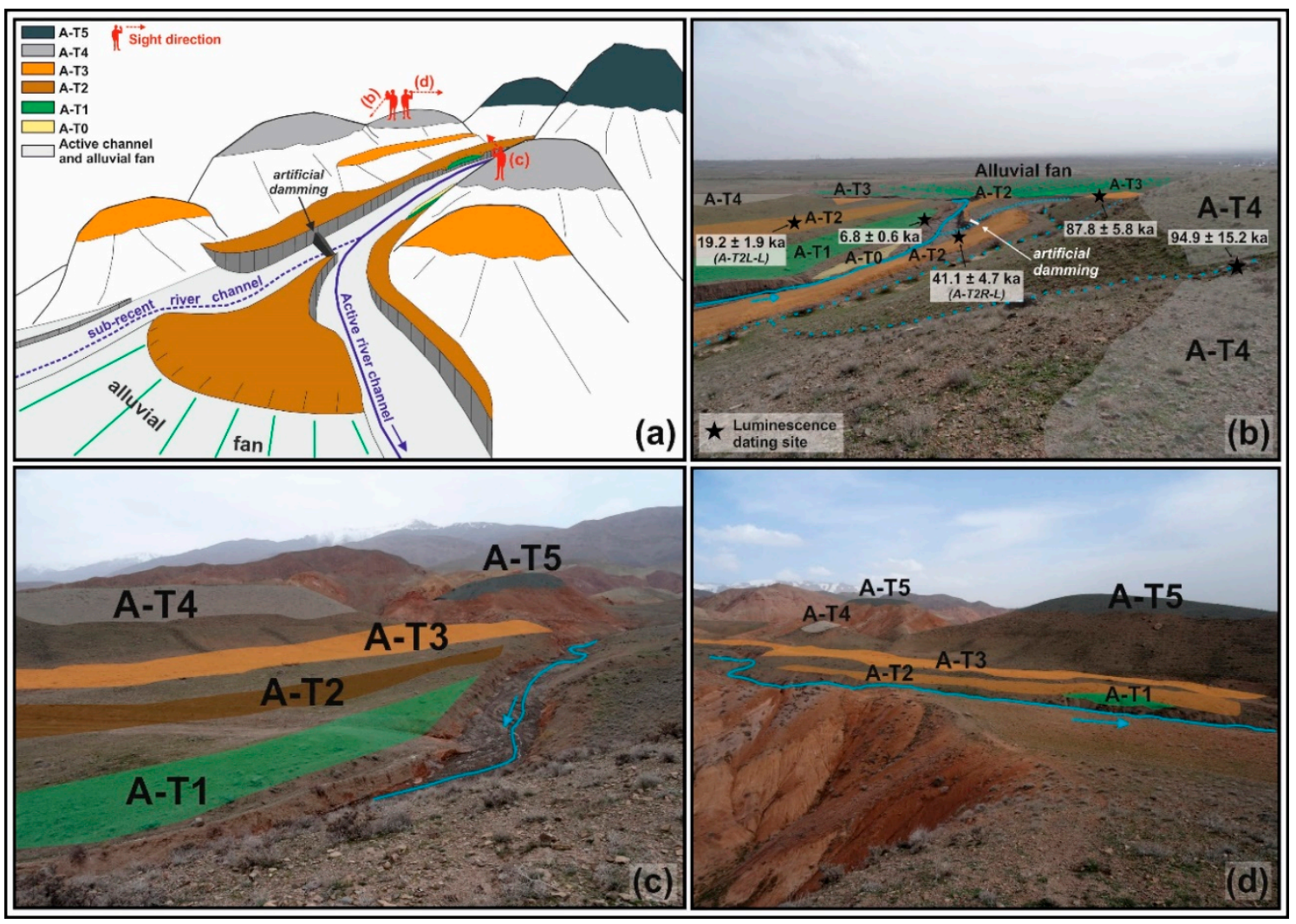

Figure 5. The studied terrace levels A-T0-A-T5 at the apex of the present-day alluvial fan with luminescence ages (location in the river system please see Figure 3). (a) Sketch of the terrace levels seen from the south with viewpoint directions of figures $(\mathbf{b}-\mathbf{d})$. (b) View over the terrace levels from north to south with the present-day alluvial fan in the background. (c) View over the terrace levels from southwest to northeast with the Binaloud Mountains in the background. (d) View over the terrace levels from west to east with the Binaloud Mountains in the background.

\subsubsection{Present-Day Alluvial Fan}

Based on different altitudes, and on incision and denudation features formed after fluvial aggradation, we identified five different surface generations and named them I to V (Figure 6). Due to significant incision following formation of generations I-III, these are separated from the lower-lying generations IV (IV-A in the western and IV-B in the eastern part of the fan) and V with scarps of ca. 1-1.5 $\mathrm{m}$ that gradually disappear downstream. The current river channel runs in the eastern part of the fan towards the southeast. Furthermore, at the fan apex a sub-recent channel deviates from the former without any morphological step in the stream bed, and crosses the central fan towards the 
southwest. According to field observations, the latter was closed with an artificial dam during the recent past (Figures 3 and 5). The youngest fan generation $V$ encompasses the area of the currently active southeastern river channel.

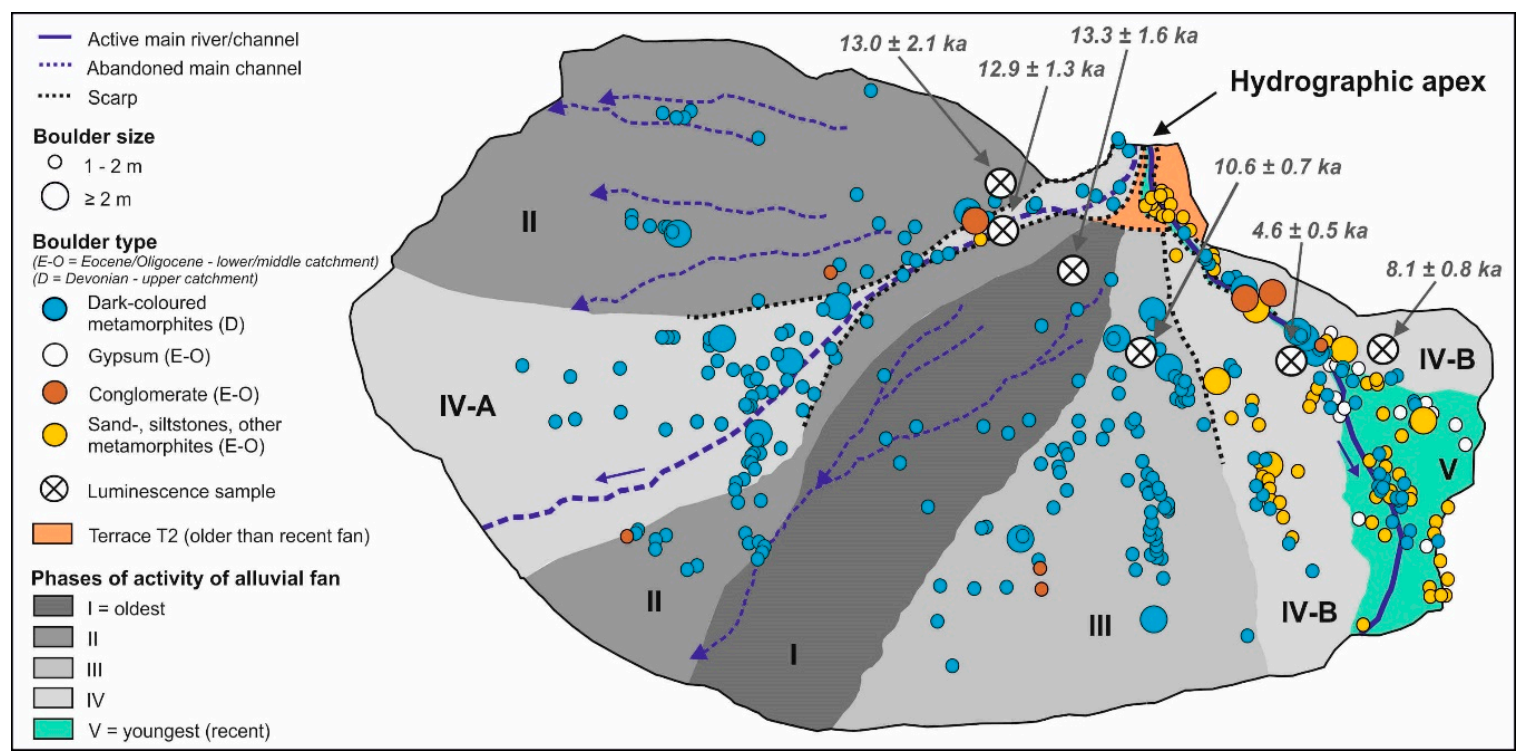

Figure 6. Geomorphological map of the present-day alluvial fan with the different fan generations I-V, luminescence ages and the distribution of boulders $>1 \mathrm{~m}$ according to size and lithology (location in the river system please see Figure 3).

All surface generations show clusters of boulders with diameters $>1 \mathrm{~m}$ (Figure 6): On surfaces I and II very low densities of 1.2 and 2.3 boulders/ha were found (Table 3), and 100-93\% are composed of Devonian dark-coloured metamorphites from the upper catchment. In contrast, on surfaces III-V the boulder densities $>1 \mathrm{~m}$ increase to $6.3-36.9$ boulders/ha, and on surfaces IV-B and V the contributions of boulders originating from the Eocene-Oligocene geology of lower and central catchment (conglomerates, gypsum, sand-/siltstones, other metamorphites) increase to $55 \%$ and $73 \%$, respectively (Table 3$)$.

Table 3. Area, and number and properties of boulders on the surfaces of the different generations of the present-day alluvial fan.

\begin{tabular}{ccccc}
\hline $\begin{array}{c}\text { Generation of Present-Day } \\
\text { Alluvial Fan }\end{array}$ & Area $\mathbf{( k m}^{\mathbf{2})}$ & Boulders $\mathbf{~ 1 ~} \mathbf{~ m / h a}$ & Boulders 1-2/>2 m & $\begin{array}{c}\text { Dark-Coloured Metamorphic } \\
\text { Boulders/Other Boulders * }\end{array}$ \\
\hline I & $0.11(16 \%)$ & 1.2 & $13 / 0(100 / 0 \%)$ & $13 / 0(100 / 0 \%)$ \\
\hline II & $0.20(30 \%)$ & 2.3 & $43 / 3(93 / 7 \%)$ & $43 / 3(93 / 7 \%)$ \\
\hline III & $0.13(19 \%)$ & 8.5 & $103 / 6(94 / 6 \%)$ & $94 / 15(86 / 14 \%)$ \\
\hline IV-A & $0.12(19 \%)$ & 6.3 & $74 / 4(95 / 5 \%)$ & $75 / 3(96 / 4 \%)$ \\
\hline IV-B & $0.07(11 \%)$ & 10.3 & $70 / 5(93 / 7 \%)$ & $34 / 41(45 / 55 \%)$ \\
\hline V & $0.04(5 \%)$ & 36.9 & $123 / 6(95 / 5 \%)$ & $37 / 92(27 / 73 \%)$ \\
\hline
\end{tabular}

* In the latter class we included boulders composed of gypsum, conglomerates, sand- and siltstones and other metamorphites, since these were mostly derived from Eocene-Oligocene deposits in the lower and central catchment. In contrast, the dark-coloured metamorphic boulders exclusively originate from Devonian rocks in the upper catchment.

\subsection{Luminescence Dating}

The values used to calculate luminescence ages, and the luminescence ages are shown in Table 1.

The IRSL-luminescence ages of the three terrace levels in the lower catchment ranged between $41.0 \pm 6.5 \mathrm{ka}(\mathrm{C}-\mathrm{T} 3)$ and $2.6 \pm 0.4 \mathrm{ka}(\mathrm{C}-\mathrm{T} 1)$, and of the terrace levels at the fan apex from $94.9 \pm 15.2 \mathrm{ka}$ 
(A-T4) to $6.8 \pm 0.6 \mathrm{ka}(\mathrm{A}-\mathrm{T} 1)$. The ages of the present-day alluvial fan ranged between $13.3 \pm 1.6 \mathrm{ka}$ (generation I) and $4.6 \pm 0.5 \mathrm{ka}$ (generation IVB).

\section{Discussion}

\subsection{The Late Quaternary Fluvial Dynamics of the Kalshur River}

During this study we independently investigated the fluvial geomorphology in three different parts of the Kalshur river system: (i) the well-developed terrace levels in lower and central catchment, (ii) the terrace levels at the fan apex, and (iii) different surface generations of the present-day alluvial fan. (i) and (ii) mostly represent older fluvial phases that were protected from subsequent fluvial erosion by their elevated topographic position. Therefore, despite the small catchment size of ca. $3.3 \mathrm{~km}^{2}$, a studied river length of only ca. $3 \mathrm{~km}$ (Figure 3) and active tectonic processes, this combined approach should allow us to better extract the effects of regional paleoenvironmental changes from those related to local tectonics or in-river processes [14]. In the following, we will discuss fluvial geomorphology and landscape evolution in the three studied parts before discussing the dynamics of the total river system:

\subsubsection{Fluvial Geomorphology and Landscape Evolution in the Three Studied Parts of the River System}

(i) The terrace staircase in lower and central catchment encompasses at least five terrace levels. Whereas the uppermost levels are mostly eroded due to intensive slope processes following their incision, and the lowest level T0 is only found at some individual locations, three well-developed terrace levels C-T1-C-T3 can be observed along the eastern and western river courses. Due to several interruptions of these levels, e.g., due to erosion by larger tributary streams, in a similar way to other river systems similar but not directly connected levels in different parts of the catchment could have formed during different periods $[4,5]$. However, despite some small interruptions, from the investigated site at the main eastern river the three levels C-T1-C-T3 could unambiguously be followed over several hundred metres upstream and downstream. According to IRSL-dating these were aggraded around 41, 22 and $2.6 \mathrm{ka}$, respectively (Figure 4). Given their long lateral continuity, fluvial aggradation was obviously not linked with local factors. Instead, against the background of an average local incision rate of roughly $0.25-0.35 \mathrm{~mm} / \mathrm{a}$ (Figure 7), the balance between water flow and sediment transport must have been influenced by regional paleoenvironmental changes [12,51]. A chronological model of the landscape evolution at the studied site in the lower catchment since about $41 \mathrm{ka}$ is given in Figure 8.

(ii) At the apex of the present-day alluvial fan, based on geomorphological observations we conclude that the currently deeply incised terrace level A-T5 with a thickness of almost 20 m must continuously have covered large areas at the southwestern forefront of the BMR, and is composed of large former alluvial fans of the Kalshur and neighbouring river systems. A-T5 was not numerically dated during this study, and traditionally its age was classified as Pliocene to early Quaternary [48]. However, using ${ }^{10} \mathrm{Be}$-dating an ubiquitously found and strongly incised alluvial surface (Q3) ca. $15 \mathrm{~km}$ northwest of our study was abandoned around $105 \mathrm{ka}$. Therefore, uplift at the southwestern margin of the BMR was reactivated not later than $100 \mathrm{ka}$ following a longer period of tectonic quiescence [40]. Since Q3 and A-T5 form the oldest surfaces in both neighbouring regions and are widely distributed and strongly incised, they probably originate from the same period. Permanent uplift at the fan apex since about $100 \mathrm{ka}$ was the precondition to form fill terrace levels A-T4-A-T0 in the newly incised Kalshur valley (Figure 7). With decreasing elevation, levels A-T4 to A-T2 systematically extend further into the southwestern foreland and obviously constitute former fan surfaces. This scenario agrees well with the regional tectonic history during the last $\approx 100 \mathrm{ka}$, according to which the front of the BMR initially corresponded to the Barfriz Fault (Figure 3). Subsequently, new faults formed basinward so that a new mountain front was formed in the southwest. During this process older alluvial fans were tilted, faulted, and incorporated within the foothills domain. Finally, the Barfriz fault has been abandoned and is now located in the interior of the range, and new fans developed basinward 
(see [40] for more details). Consequently, since the fan permanently prograded into its foreland it constitutes a telescopic alluvial fan [52] (Figure 5a). Levels A-T4 and A-T3 were dated to $95 \pm 15$ and $88 \pm 6 \mathrm{ka}$, respectively, and could continuously be followed over several hundred metres upstream from the apex (Figure 5b,c). Also level A-T2 could be followed over larger distances (Figure 5b-d). However, similar to other river systems [4,5] different luminescence ages for sediments of the right bank (41 $\pm 5 \mathrm{ka}$; sample A-T2R) and left bank (19 $\pm 2 \mathrm{ka}$; sample A-T2L) of the river demonstrate sediment aggradation in this morphological terrace level during two different periods. This can possibly be explained with the very low average local incision rate of roughly $0.1-0.05 \mathrm{~cm} /$ a during its formation, so that the fluvial sediments were not protected against subsequent erosion and renewed sediment deposition by fast lowering of the active river bed (Figure 7). In contrast, given the relatively high average local incision rate of roughly $1.3 \mathrm{~mm} / \mathrm{a}$ during formation of levels A-T4 and A-T3, the river bed was lowered too fast to allow aggradation at the same altitude during longer time (Figure 7). Therefore, given that A-T4 and A-T3 with sediment thicknesses of 10 and $4 \mathrm{~m}$ (Table 2) were probably aggraded during relatively short periods, these should manifest reactions of the river towards external paleoenvironmental changes rather than to local factors. In contrast, at least for one of the two periods that aggraded sediments in morphological terrace level A-T2, small-scale aggradation due to local factors cannot be excluded, since the lateral and vertical extension of the sediments from these two different periods cannot be evaluated. Level A-T1 with a luminescence age of $6.8 \pm 0.6 \mathrm{ka}$ and level A-T0 were only found in smaller areas along the river course (Figure 5). Consequently, these levels could also potentially contain sediments from different periods at different locations, or could at least partly be linked with local rather than with regional paleoenvironmental factors. A chronological model of the landscape evolution at the fan apex since ca. $100 \mathrm{ka}$ is given in Figure ??.

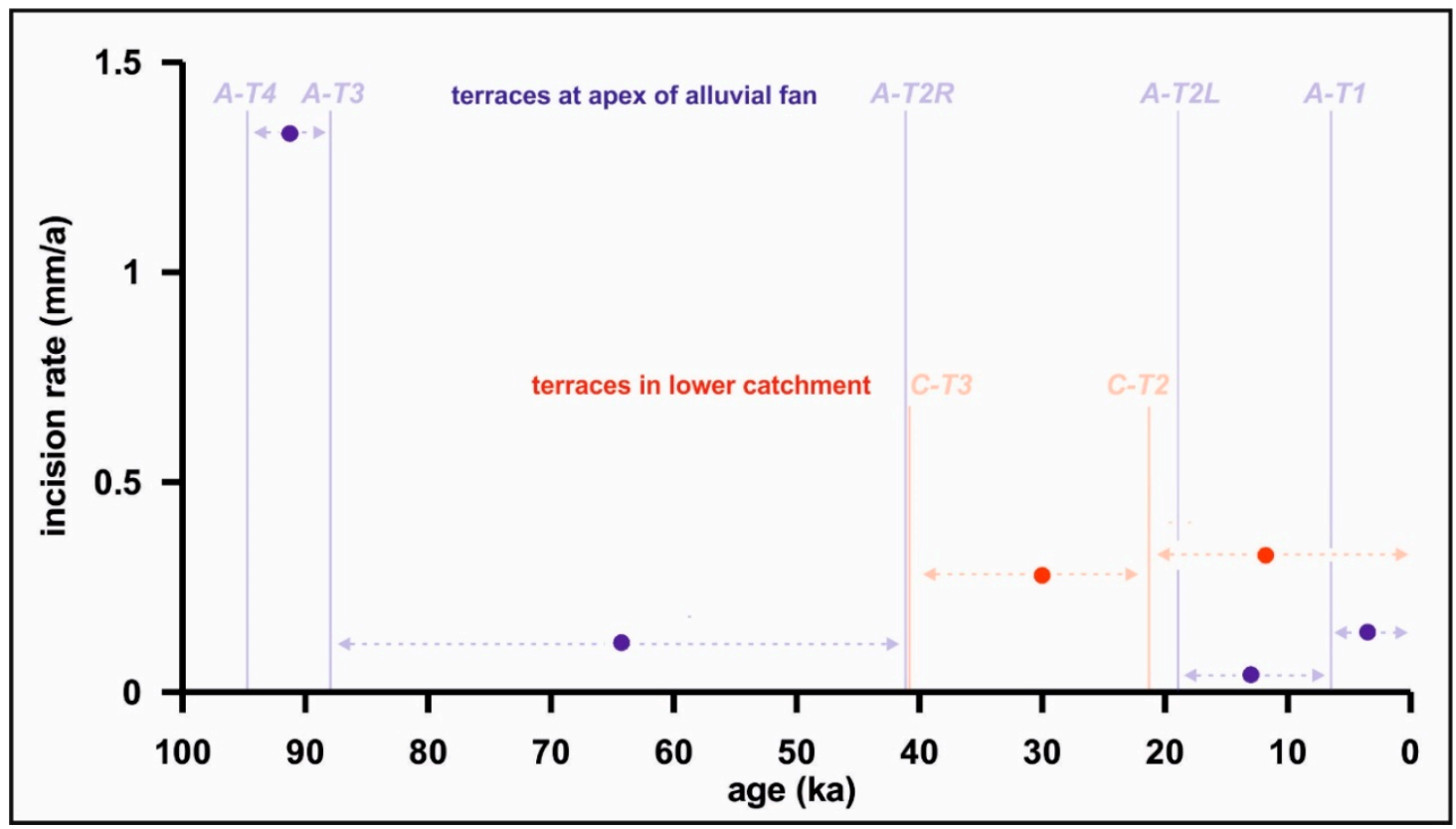

Figure 7. Approximate average local incision rates for the investigated sites at the main eastern river in the lower catchment (red circles) and at the apex of the present-day alluvial fan (blue circles). The rates were derived by relating bedrock incision between the dated fluvial terrace levels with the elapsed time. However, one should be aware that the averaged erosion rates possibly encompass shorter periods of higher and lower rates than the averages. The luminescence ages of the terrace levels (without errors) are shown with solid vertical lines. 


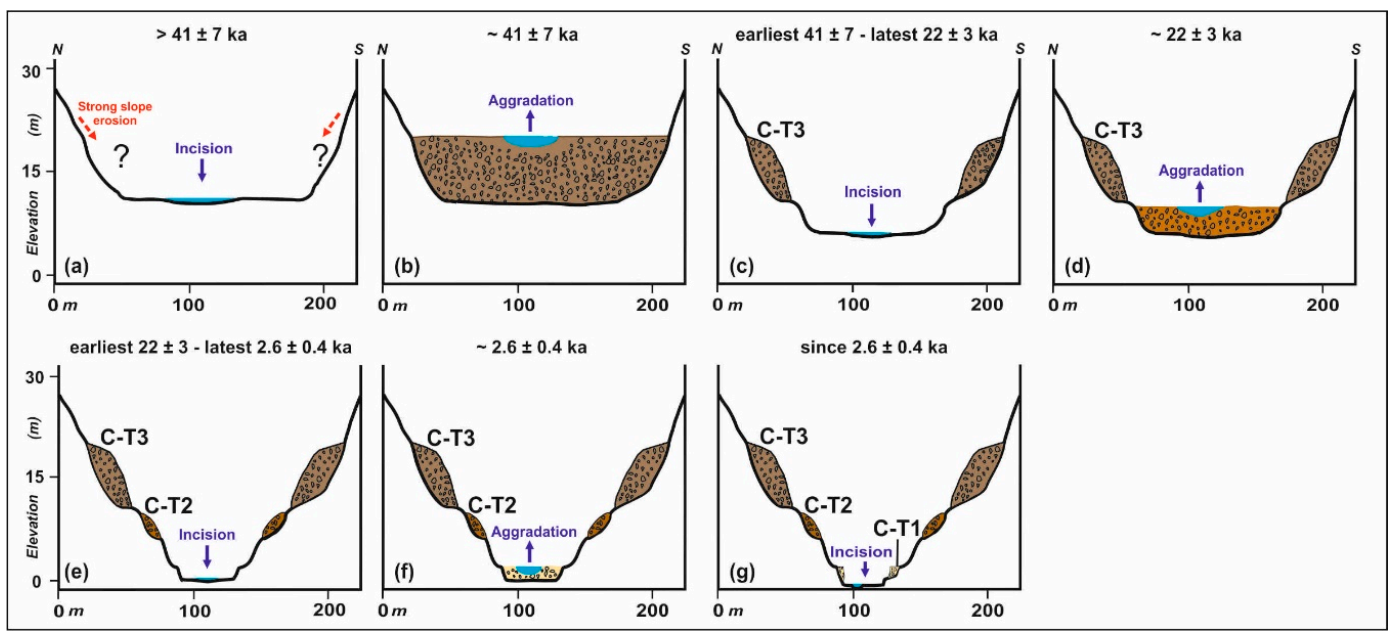

Figure 8. Schematic model of the landscape evolution at the studied site at the main eastern river in the lower catchment since ca. $41 \mathrm{ka}$ (location in the river system please see Figure 3). (a) $>41 \pm 7 \mathrm{ka}$, (b) $\approx 41 \pm 7 \mathrm{ka}$, (c) earliest $41 \pm 7$-latest $22 \pm 3 \mathrm{ka},(\mathbf{d}) \approx 22 \pm 3 \mathrm{ka}$, (e) earliest $22 \pm 3$-latest $2.6 \pm 0.4 \mathrm{ka}$, $(\mathrm{f}) \approx 2.6 \pm 0.4 \mathrm{ka},(\mathrm{g})$ since $2.6 \pm 0.4 \mathrm{ka}$. Please note that the aggradation periods can have lasted longer than the respective luminescence ages with their error ranges.

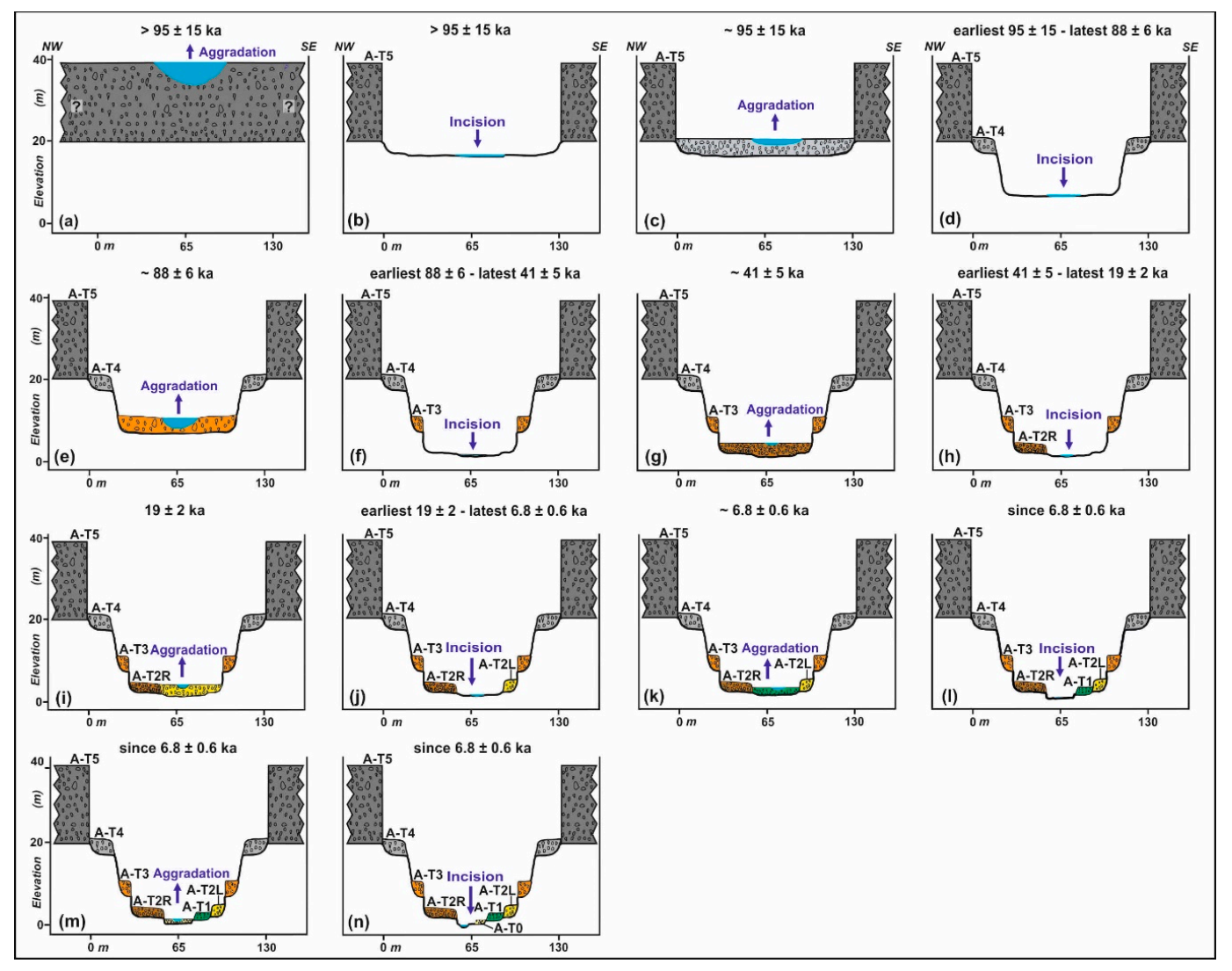

Figure 9. Schematic model of the landscape evolution at the apex of the present-day alluvial fan since ca. $100 \mathrm{ka}$ (location in the Kalshur river system please see Figure 3). (a) $>95 \pm 5 \mathrm{ka}$, (b) $>95 \pm 5 \mathrm{ka}$, (c) $\approx 95 \pm 5 \mathrm{ka}$, (d) earliest $95 \pm$ 5-latest $88 \pm 6 \mathrm{ka},(\mathbf{e}) \approx 88 \pm 6 \mathrm{ka}$, (f) earliest $88 \pm 6$-latest $41 \pm 5 \mathrm{ka}$, $(\mathrm{g}) \approx 41 \pm 5 \mathrm{ka}$, (h) earliest $41 \pm 5$-latest $19 \pm 2 \mathrm{ka},(\mathbf{i}) \approx 19 \pm 2 \mathrm{ka}$, (j) earliest $19 \pm 2$-latest $6.8 \pm 0.6 \mathrm{ka}$, $(\mathbf{k}) \approx 6.8 \pm 0.6 \mathrm{ka},(\mathbf{i})$ since $6.8 \pm 0.6 \mathrm{ka},(\mathbf{m})$ since $6.8 \pm 0.6 \mathrm{ka},(\mathbf{n})$ since $6.8 \pm 0.6 \mathrm{ka}$. Terrace level A-T5 most likely corresponds to surface Q3 of [40]. Please note that the aggradation periods can have lasted longer than the respective luminescence ages with their error ranges. 
(iii) Surface generation I of the present-day alluvial fan was dated with luminescence to $13.3 \pm 1.6 \mathrm{ka}$, generation II to $12.9 \pm 1.3$ and $13.0 \pm 2.1 \mathrm{ka}$, and generation III to $10.6 \pm 0.7 \mathrm{ka}$ (Figure 6). Therefore, aggradation lasted for about two to three millennia during and after the Pleistocene/Holocene transition. Two luminescence ages of $8.1 \pm 0.8$ and $4.6 \pm 0.5 \mathrm{ka}$ from lower-lying generation IV indicate its aggradation during several millennia since at latest ca. $8 \mathrm{ka}$. The youngest generation $\mathrm{V}$ gradually passes over into generation IV, and was only found along the current southeastern but not along the artificially dammed sub-recent southwestern channel. Therefore, generation V obviously represents fluvial activity after artificial damming of the latter during the last decades, and should be regarded as the youngest part of generation IV. Given that the elevation of generations IV and V is ca. $1-1.5 \mathrm{~m}$ lower than that of generations I-III, significant incision must have occurred between ca. 10.5 and $8 \mathrm{ka}$. Since then fluvial activity was confined to two smaller incised areas that only comprise ca. 35\% of the fan surface (Table 3). Several clusters of boulders $>1 \mathrm{~m}$ are found on the fan surface. Whereas Latest Pleistocene surface generations I and II show generally low boulder densities, starting with generation III these strongly increase. This indicates a more intensive boulder transport since the early Holocene (Figure 6, Table 3). Most boulders not consisting of dark-coloured metamorphites, originating from the Eocene to Oligocene geology of lower and central catchment, were found on surfaces IV-B and V along the currently active southeastern river channel. Therefore, they must have been deposited during the last decades. A schematic model of the evolution of the present-day alluvial fan since ca. $13 \mathrm{ka}$ is given in Figure 10.

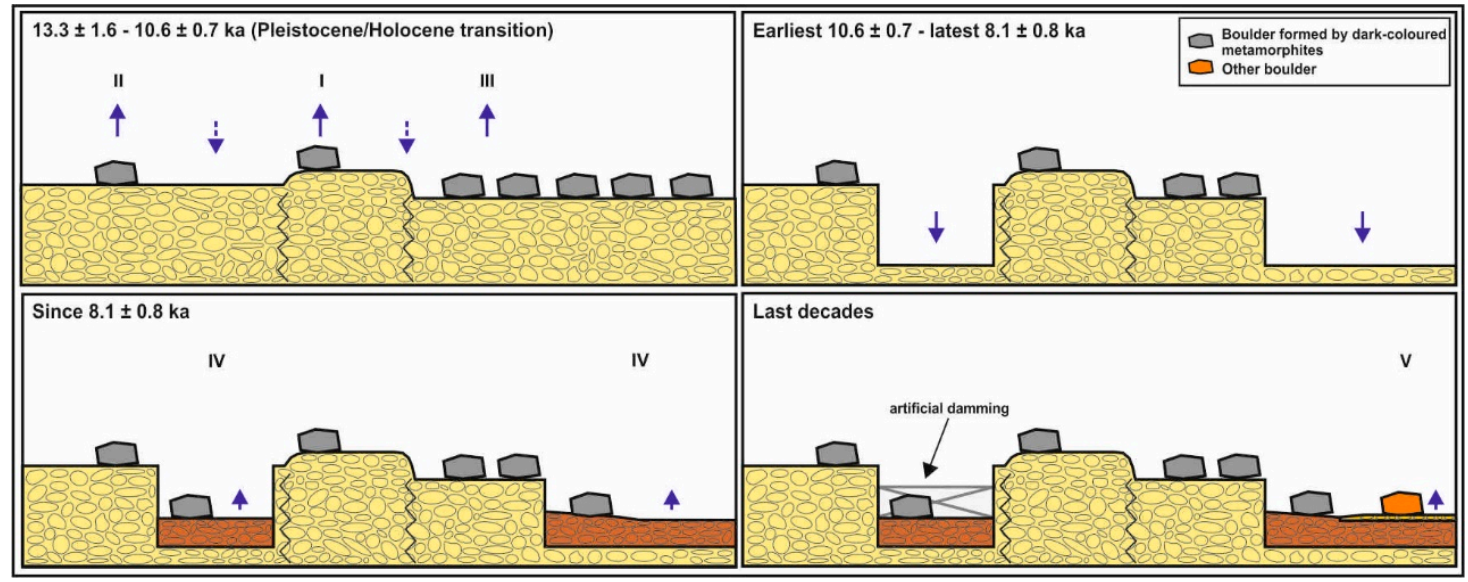

Figure 10. Schematic model of the evolution of the present-day alluvial fan since ca. 13 ka (location in the river system please see Figure 3).

\subsubsection{Fluvial Dynamics of the Kalshur River System}

During this study we identified several main periods of fluvial aggradation and incision. Whereas some were observed in different parts of the river system and, therefore, indicate fluvial reactions towards external paleoenvironmental factors, others were only detected in one part. In the latter case, it is possible that large-scale aggradation occurred but was not recorded due to: (i) missing preservation of primarily deposited sediments caused by strong slope erosion, or by autogenic in-river processes that locally removed formerly deposited sediments [53]; (ii) no numerical dating of fluvial sediment units due to their missing recognition in the field; (iii) limited accommodation space in narrow valleys, hindering aggradation or causing fast erosion of primarily deposited sediments [54]. However, it is also possible that sediments were only aggraded in small areas due to high local sediment input linked with sediment delivery, e.g., from small alluvial fans [13] or landslides. The latter scenario is often linked with seismotectonic activity: Depending on the distance from the rupture zone, either landslide-triggered local sediment input with aggradation or local incision is found [55]. Therefore, to only interpret fluvial phases that are probably linked with regional paleoenvironmental 
changes influencing the balance between water flow and sediment load in favour of the latter [12,51], we concentrated on periods with significant fluvial aggradation either at two different locations or over larger areas (Figure 11):

- $\quad$ Between ca. 95 and $88 \mathrm{ka}$ (late marine isotope stage [MIS] 5): after the restart of regional uplift in the southwestern BMR ca. $100 \mathrm{ka}$ [40], the river started to incise at the apex of the present-day alluvial fan. Shortly afterwards, incision was interrupted two times by the aggradation of terrace levels A-T4 and A-T3 that both show sediment thicknesses of $4 \mathrm{~m}$. In contrast, no fluvial deposits from this period were found in the lower catchment. However, some small remnants of terraces above C-T3 demonstrate terrace aggradation prior to $41 \mathrm{ka}$ also in this area, but these were largely eroded by subsequent slope processes. Given the large lateral extension and thickness of the deposits of A-T4 and A-T3 at the fan apex, this indicates an intensive fluvial dynamics with two periods of strong aggradation.

- Around $40 \mathrm{ka}$ (MIS 3): during this time terrace level C-T3 with a sediment thickness of ca. $10 \mathrm{~m}$ was aggraded in the lower catchment. At the fan apex, the older sediments forming terrace level A-T2 with a thickness of ca. $3.5 \mathrm{~m}$ were aggraded. Given the large thickness of the deposits in the lower catchment and aggradation in two different parts of the river system, this indicates a period of intensive fluvial dynamics with strong aggradation.

- Around $20 \mathrm{ka}$ (MIS 2): during this time terrace level C-T2 with a sediment thickness of ca. $4 \mathrm{~m}$ was aggraded in the lower catchment, and at the fan apex the younger sediments forming terrace level A-T2. Also during this time thick sediments were aggraded at least in the lower catchment, and sediments were aggraded in two different parts of the river system. Therefore, also this period was obviously characterized by an intensive fluvial dynamics with strong aggradation.

- Around 13.0-10.5 ka (transition MIS2/1 = Pleistocene/Holocene transition): during this period the older higher-elevated part of the present-day alluvial fan (surface generations I-III) was aggraded, and must have covered the total fan area of at least $0.66 \mathrm{~km}^{2}$. As indicated by the formation of three individual surface generations, this time was characterized by an intensive fluvial dynamics with several periods of aggradation and incision. In contrast, no fluvial sediments from this period were found in the lower catchment and at the fan apex. In both areas, incision of terrace levels C-T2 and A-T2 after ca. 20 ka had formed valleys with relatively small widths of only ca. 50 and 40-105 m, respectively. Therefore, it is very likely that due to the very limited accommodation space most sediments from that time were subsequently largely eroded. Consequently, individual remains of terrace level A-T1 at the fan apex that were not numerically dated could possibly originate from this time [54].

- Since ca. 10.5 ka (MIS 1: Holocene): terrace level C-T1 in the lower catchment was dated to ca. $2.6 \mathrm{ka}$. This level could be followed over several hundred metres, indicating that it could perhaps represent the reaction of the river towards a regional environmental signal. In contrast, a residue of terrace level A-T1 at the fan apex with an age ca. $6.8 \mathrm{ka}$ had a much smaller spatial extension, and level A-T0 was not numerically dated at all. Therefore, these cannot be interpreted here. The older part of the present-day alluvial fan was largely incised between ca. 10.5 and $8 \mathrm{ka}$, and subsequently surface generations IV and V were aggraded without prominent morphological structures. Therefore, the two ages of 8.1 and $4.6 \mathrm{ka}$ from generation IV cannot be ascribed to certain aggradation periods. The density of large boulders $>1 \mathrm{~m}$ increases on Holocene surfaces III-V compared with Latest Pleistocene surfaces I-II. Such boulders on alluvial fans probably originate from debris flows linked with flash floods [24,56]. Therefore, Holocene flash flood intensity probably increased since the early Holocene. Altogether, apart from large-scale incision of the current fan between ca. 10.5 and $8 \mathrm{ka}$, a possibly increased flash flood intensity since the early Holocene, and may be the aggradation of C-T1 in the lower catchment ca. $2.6 \mathrm{ka}$, no further paleoenvironmental interpretation can be derived from the Kalshur river system for most of the Holocene. 
- Last decades: the relative and absolute quantity of large boulders from the Eocene to Oligocene geology of lower and central catchment strongly increased on fan surface generations IVB and V. Since these were the only active parts of the present-day alluvial fan since artificial damming of the sub-recent southwestern channel probably some decades ago, this indicates strongly intensified erosion in these areas with the mobilisation of large boulders during the last decades.

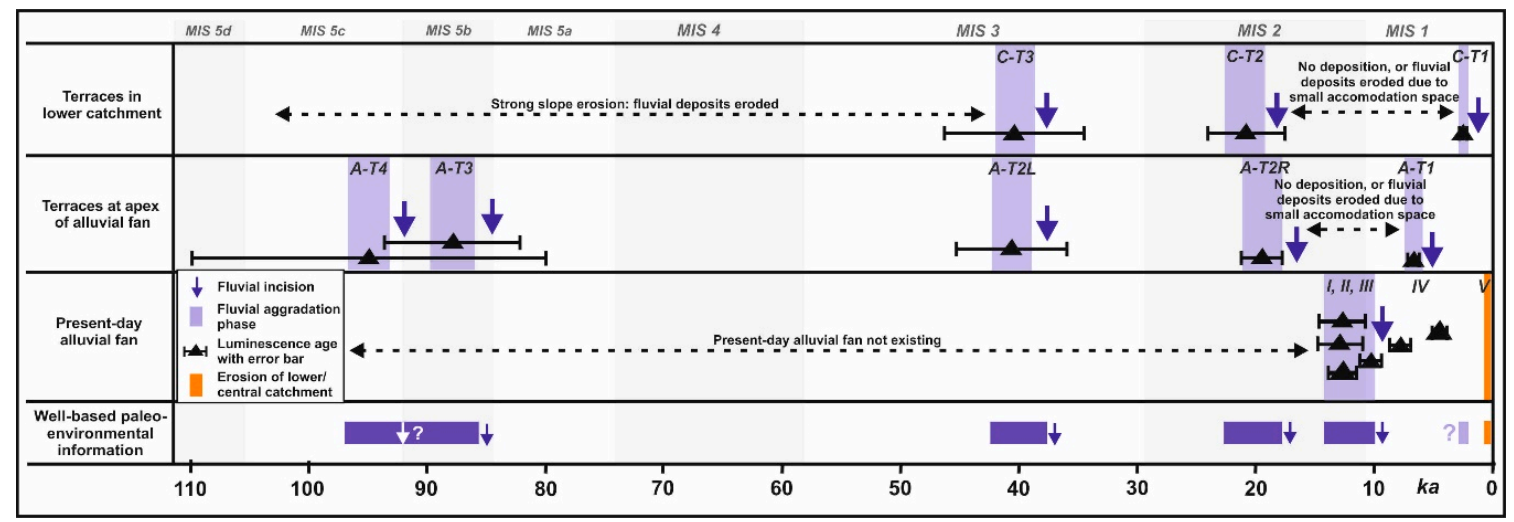

Figure 11. The late Quaternary fluvial dynamics in the three individually studied parts (upper part), and consequently derived well-based paleoenvironmental information from the total Kalshur river system (lower part). The latter represent fluvial aggradation phases that were independently identified in larger areas or in different parts of the river system, or are based on the observation of strongly increased proportions of boulders from the lower and central catchment.

\subsection{Possible Environmental Causes of the Observed Fluvial Dynamics of the Kalshur River System}

By comparing our results with regional paleoenvironmental studies and over-regional temperature and solar data, we tried to find possible explanations for observed Late Quaternary changes of the balance between water flow and sediment transport in the Kalshur river system that are expressed by aggradation (sediment overload) and incision (dominance of water flow) [12,51].

\subsubsection{Late Pleistocene}

Unfortunately, Late Pleistocene paleoenvironmental records are very rare in the drylands of eastern and northeastern Iran: only two studies document periods of fluvial incision that roughly coincide with incision in the Kalshur river system [37,38] (locations see Figure 1). Furthermore, loess-paleosol-sequences in the Iranian Caspian Lowland and the neighbouring Iranian Loess Plateau show periods of soil formation and large-scale loess erosion, giving information about more humid phases and periods of intensive precipitation [32-35] (locations see Figure 1). Unfortunately, loess-paleosol sequences in the periphery of the BMR and the Kopeh Dagh Mountains show rather low chronological resolutions for most of the Late Pleistocene, and can therefore not be compared with our fluvial record for this period [30,31].

- Late MIS5: aggradation and incision of the large-scale terrace levels A-T4 and A-T3 at the fan apex obviously started during the later part of substage $5 \mathrm{~d}$, and possibly lasted until the earlier part of substage 5a. The loess-paleosol sequences in northern Iran show soil formation during warmer substages $5 \mathrm{a}$ and $5 \mathrm{c}$ attributed to more humid conditions, whereas colder substage $5 \mathrm{~b}$ showed loess deposition and was, therefore, interpreted as a drier period [34] (Figure 12a,d). This demonstrates fluctuating regional climate conditions during that time. In the Kalshur river system, these probably changed the balance between sediment overloading due to intensive sediment production e.g., by frost weathering in the high mountain catchment and/or less discharge leading to aggradation, and more discharge and/or less sediment production leading to fluvial incision: the first scenario most likely occurred during colder and drier periods, and the latter 
probably during warmer and more humid conditions. Similarly, based on ${ }^{36} \mathrm{Cl}$-dating incision of the Namanlu fan in the Kopeh Dagh Mountains occurred at latest during 83 ka (Figure 12b) [37]. Likewise, incised Quaternary river deposits at the Neyshabour Fault at the southwestern foothill of the BMR ca. $30 \mathrm{~km}$ northwest of our study area gave a luminescence age of $82.3 \pm 7 \mathrm{ka}$ [38] (Figure 12c).

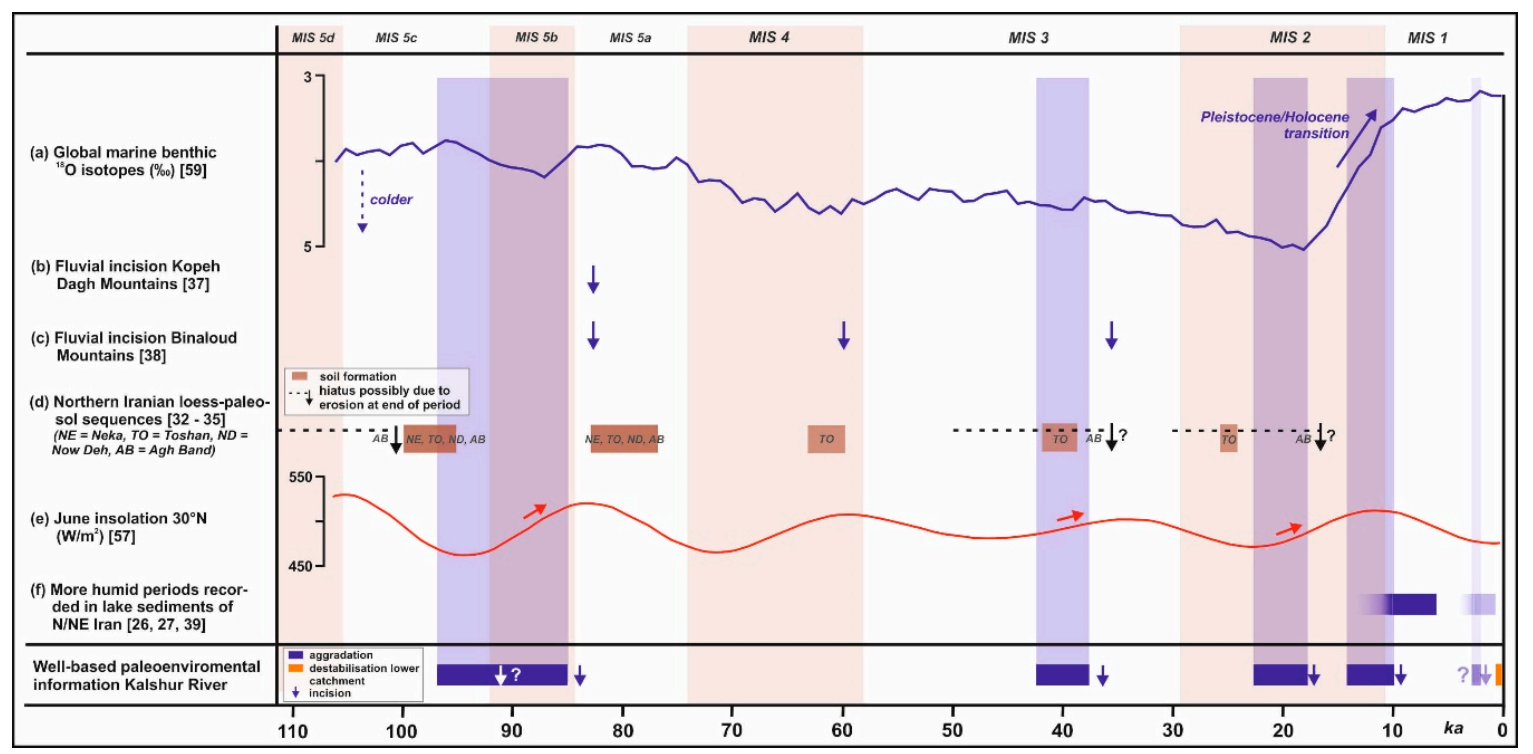

Figure 12. Comparison of well-based paleoenvironmental information from the Kalshur river system (lower part) with regional and over-regional paleoenvironmental data: (a) Global marine benthic ${ }^{18}$ O isotopes, (b) Fluvial incision Kopeh Dagh Mountains, (c) Fluvial incision Binaloud Mountains, (d) Northern Iranian loess-paleosol-sequences, (e) June insolation $30^{\circ} \mathrm{N}$, (f) More humid periods recorded in lake sediments of N/NE Iran. Locations of the regional study sites please see in Figure 1.

- $\quad$ Around $40 \mathrm{ka}$ (MIS 3): during this time terrace level C-T3 in the lower catchment and the older sediments of level A-T2 at the fan apex were aggraded and subsequently incised. At the same time a weak soil formed in the loess-paleosol sequence Toshan in northern Iran, pointing to a slightly more humid regional climate [32,34]. In contrast, the more eastward located Agh Band loess-paleosol sequence shows a hiatus between ca. 50 and $34 \mathrm{ka}$ due to missing loess sedimentation or strong erosion (Figure 12d). In the latter case, erosion must have been caused by intensive precipitation prior to ca. $34 \mathrm{ka}$ [33]. Therefore, higher discharge due to intensive precipitation could have caused incision in the Kalshur river system after ca. $40 \mathrm{ka}$. Similarly, uplifted and incised Quaternary river deposits at the Neyshabour Fault ca. $30 \mathrm{~km}$ northwest of our study area were dated with luminescence to $35.4 \pm 6 \mathrm{ka}$ [38] (Figure 12c).

- $\quad$ Around $20 \mathrm{ka}$ (MIS 2): during this time, terrace level C-T2 in the lower catchment and the younger part of level A-T2 at the fan apex were aggraded and subsequently incised. In the Toshan loess-paleosol sequence a weak paleosol formed around 26-25 ka, indicating a short more humid phase during a generally arid period [32]. In contrast, the Agh Band loess-paleosol sequence shows a hiatus between ca. 30 and $16.7 \mathrm{ka}$ (Figure 12d). As before, this hiatus could have been caused by missing loess sedimentation or strong erosion, and in the latter case strong precipitation prior to ca. 16.7 ka could have caused erosion [33]. Therefore, aggradation in the Kalshur river system could have occurred during regionally drier conditions that still allowed fluvial sediment transport, and following incision was caused by subsequent intensive precipitation events leading to strong river discharge.

However, care must be taken with the interpretations made above: on the one hand, all compared fluvial sites show different local tectonic contexts. On the other hand, unlike the BMR the loess-paleosol 
sequences in northern Iran were also significantly influenced by fluctuations of the Caspian Sea level, i.e., they were also sensitive towards more local effects [32-35].

Another interesting explanation for the Late Pleistocene dynamics of the Kalshur river system is offered by comparing it with June insolation at $30^{\circ} \mathrm{N}$ [57] (Figure 12e): Fluvial aggradation and subsequent incision during late MIS5, ca. 40 and $20 \mathrm{ka}$ occurred during the rising limbs of summer insolation in the northern hemisphere. Increasing summer insolation leads to larger intra-annual temperature contrasts between winter and summer, resulting in a shorter and, therefore, more accentuated snow melt season during late spring and summer. This should have caused more intensive flooding during that season [7]. Furthermore, [58] demonstrate a much lower permafrost limit for the Last Glacial Maximum (LGM) compared with today, reaching down to ca. 900-1000 m a.s.l. at ca. $43^{\circ} \mathrm{N}$ in Kazakhstan. Accordingly, these authors indicate LGM-permafrost also for the BMR. Given that our studied catchment extends between ca. 1400 and $2100 \mathrm{~m}$ a.s.l., at least in its upper part permafrost should have existed during most of the Weichselian period. Increasing summer insolation should have caused deeper thawing of the upper permafrost layer during the warm season. Therefore, it is also possible that with increasing summer insolation permafrost thawing released large amounts of primarily produced loose periglacial material, causing sediment overloading with fluvial aggradation. Subsequently, when most material was removed from the slopes decreasing sediment load in the river could have led to fluvial incision. A similar effect was also observed for river systems draining the Lesser Caucasus, where strong aggradation during the latest Pleistocene was probably caused by large-scale transport of periglacial material that was produced during the preceding millennia. After removing most of these sediments the rivers started to incise [6].

\subsubsection{Since the Pleistocene/Holocene Transition}

During the Pleistocene/Holocene transition the global climate system changed from a glacial to an interglacial state [59] (Figure 12a). This must also have affected the dynamics of the Kalshur river system.

- Following final incision of terrace level A-T2 at the fan apex after ca. $20 \mathrm{ka}$, the older fan surfaces were aggraded between ca. 13 and 10.5 ka, i.e., around and after the Pleistocene/Holocene transition (Figure 12a). Concomitant aggradation of other alluvial fans in the region was also described by [19], although those authors suggest continuous aggradation since ca. $30 \mathrm{ka}$. In the loess section Kalat-e-Naderi in the Kopeh Dagh Mountains north of the BMR, loess deposition linked with cold and arid climate conditions ended ca. $13.7 \pm 1.3 \mathrm{ka}$. This possibly indicates a less arid regional climate since then [31] (location see Figure 1), causing generally increased river flow. Together with final permafrost decay in the catchment, successively releasing large amounts of primarily produced loose periglacial material causing sediment overloading, this should have resulted in aggradation of the Kalshur river system. Repeated aggradation and incision periods, forming fan surfaces I-III, are possibly explained with climatic fluctuations during that time (warmer Bölling/Alleröd interstadial ca. 14.7-12.9 ka, colder Younger Dryas stadial ca. 12.9-11.7 ka, start of Holocene since ca. $11.7 \mathrm{ka}$ ) [60]. The much higher density of boulders $>1 \mathrm{~m}$ on Holocene surfaces III-V compared with Latest Pleistocene surfaces I and II indicates a general climatic shift during this time, since the boulders were probably transported by debris flows linked with flash floods $[24,56]$. Therefore, our data indicate more flash floods since the early Holocene.

- Similar to other regional fans $[19,25]$, the older fan surfaces I-III were incised after ca. $10.5 \mathrm{ka}$. This reflects a dominance of river flow compared with sediment load possibly due to more humid conditions: Accordingly, a more humid regional climate between at least 10 and $6 \mathrm{ka}$ is indicated by lake formation in the South Golbaf Basin in southeastern Iran between ca. 13.5 and $6.3 \mathrm{ka}$ [26], and in the Nimbluk Plain in northeastern Iran at least between ca. 9.9 and 7.3 ka [27] (Figure 12f; locations see Figure 1). A more humid climate is also reported from neighbouring Central Asia for this time [61]. 
- Incision of the older fan surfaces was completed at latest ca. $8 \mathrm{ka}$. Subsequently, only few well-based paleoenvironmental information can be derived from the Kalshur river system: Only terrace level C-T1 in the lower catchment with an age of ca. $2.6 \pm 0.4$ ka extends over a larger area, and might, therefore, reflect a regional environmental signal. A generally drier climate in eastern and northeastern Iran since the Middle to Late Holocene is suggested by [19] and [26]. However, sediments from Kongor Lake in northeastern Iran [29] suggest a more humid period since ca. $3.9 \mathrm{ka}$ that peaked between ca. 2.7 and $0.7 \mathrm{ka}$ (Figure 12f; location see Figure 1). These humidity fluctuations should also have influenced the Kalshur river system, and are eventually linked with the formation of terrace level C-T1 in the lower catchment. Interestingly, ca. $20 \mathrm{~km}$ northwest of the study area a Bronze Age settlement was buried by fluvial deposits about $3.5 \mathrm{ka}$ [45].

- Finally, the strong relative and absolute increase of boulders from the lower and central catchment on fan surfaces IVB and V compared with the older surfaces is remarkable. Given that only the former were active since artificial damming of the sub-recent southwestern channel probably some decades ago, this indicates more intensive erosion in lower and central catchment since that time. That erosion was most likely linked with intensified seasonal herding by regional shepherds. Accordingly, increasing human pressure on the natural resources was observed all over Iran especially since the 1970s to 1980s [62]. The strong geomorphic activation of the lower and central catchment by human activity indicates the generally high sensitivity of fragile drylands towards external anthropogenic triggers [63].

All studied sites are located in the Buzhan Fault zone, i.e., the currently active frontal fault zone of the BMR foothills [40]. That fault zone is characterized by several parallel fault segments and, therefore, extends over a larger area (Figure 3). Thus, we cannot totally exclude a local tectonic cause also in the case that aggradation or incision were simultaneously observed in different parts of the catchment or over larger areas. Furthermore, also in case of a coincidence between such fluvial periods with regional geomorphological and hydrological changes or the over-regional solar and temperature dynamics, it may be possible that this is just a coincidental match but was not causally linked with each other. However, such effects should have been exceptions rather than the rule. Consequently, despite those uncertainties we suggest that similar to larger river systems [6,14,64,65] also the late Quaternary fluvial dynamics of the Kalshur river system with a catchment of just some square kilometres were obviously mostly dominated by environmental factors. Therefore, besides showing an influence of global temperature fluctuations on the fluvial dynamics, our study (i) obviously confirms the regional extent of late Quaternary hydro-climatic fluctuations in the drylands of eastern and northeastern Iran that were formerly detected in loess-paleosol sequences, fluvial and lake sediments, and (ii) shows the severe consequences of human activity for the landscape dynamics of the BMR during the last decades.

\section{Conclusions}

In this study, using a combined approach, we exemplarily investigated the Late Pleistocene and Holocene dynamics of the small Kalshur river system with a catchment of some square kilometers at the southwestern margin of the Binaloud Mountain Range in the drylands of northeastern Iran. Our approach encompassed independent investigations of different parts of the river system by means of geomorphological and numerical dating methods. Doing so, we identified several aggradation and incision periods that concomitantly occurred in different parts of the river system. Despite a general scarcity of regional paleoenvironmental data from the drylands of eastern and northeastern Iran, these periods were obviously concomitant with regional geomorphological and hydrological changes, but also with the over-regional solar and temperature dynamics. Therefore, despite strong local seismo-tectonic activity, we suggest that the fluvial dynamics of the Kalshur river system was obviously mostly controlled by regional hydro-climatic changes or human activity. Consequently, our findings suggest that despite their small size such river systems form valuable paleoenvironmental archives in drylands that cover almost half of the global land surface, and where other types of archives are often largely missing. However, since small river systems often originate from more humid high 
mountain ranges, their Pleistocene dynamics could at least partly also have been controlled by the permafrost dynamics in their catchments. Therefore, in some cases the extracted information may only be of limited value for paleoenvironmental reconstructions of the surrounding drylands. Consequently, a comparison with other regional and over-regional paleoenvironmental studies is always mandatory. Concerning the time span covered by our study, it turned out that, due to much less post-sedimentary erosion, the oldest fluvial sediments were found at the fan apex and not in the catchment. Therefore, although quite robust paleoenvironmental information can be obtained from small river systems when using our combined approach, the time span of such reconstructions is not necessarily enlarged compared with studies that only focus on the current alluvial fan and adjacent older fan generations.

Supplementary Materials: The following are available online at http://www.mdpi.com/2076-3263/10/11/448/s1, Table S1: Sedimentological properties of the luminescence dating sites, Table S2: post-IRSL (pIRIR) protocol, Table S3: Generalized single-aliquot regenerated sequence, Table S4: Given doses and delay times of each cycle related to the fading of exemplary samples C-T2-L and A5-L, Figure S1: Dose recovery and recycling ratio of exemplary sample A1-L (pre-heat plateau test), Figure S2: Measurements of exemplary sample A5-L (IRSL 50) (a) Decay curve, (b) Growth curve fitting, and De distribution of feldspar grains in (c) weighted mean, and (d) central age, Figure S3: Fading tests of exemplary samples C-T2-L and A5-L. The sequence of Table S2 was applied, and pre-heat and cut-heat were fixed at $320^{\circ} \mathrm{C}$. Cycle 1 is the prompt measurement, and cycles 2 to 5 represent the delays according to Table S4.

Author Contributions: Conceptualization, A.K. and H.v.S.; Methodology A.K., H.v.S., M.F. and H.A.; Investigation A.K., H.v.S., M.F. and H.A.; Writing-Original Draft Preparation A.K., H.v.S. and M.F.; Writing-Review and Editing A.K., H.v.S. and M.F.; Visualization A.K., H.v.S. and M.F.; Project Administration A.K. and H.v.S. All authors have read and agreed to the published version of the manuscript.

Funding: The stay of Azra Khosravichenar in Leipzig was funded for six months with a grant of the sabbatical program for doctoral students of the Ministry of Science, Research and Technology of Iran.

Acknowledgments: We thank Mohamed Fatemi and Rama Khosravichenar (both Mashhad), Ulrich Göres (Dresden) and Klaus von Suchodoletz (Ballwitz) for their help during field work, as well as Mehdi Torabi and Latif Seyd Mohamadi for their help during luminescence sample preparation. Esmaeil Shabanian (Zanjan) is acknowledged for discussions on the tectonics of NE Iran, and Christopher Roettig (Dresden) for a critical revision of the manuscript prior to submission. Furthermore, we are indebted to Peter Thorn (Oxford) for checking the English language, and to three anonymous reviewers for their valuable comments on a first version of this manuscript. We acknowledge support from Leipzig University for Open Access Publishing.

Conflicts of Interest: The authors declare no conflict of interest.

\section{References}

1. Macklin, M.G.; Benito, G.; Gregory, K.J.; Johnstone, E.; Lewin, J.; Michczynska, D.J.; Soja, R.; Starkel, L.; Thorndycraft, V.R. Past hydrological events reflected in the Holocene fluvial record of Europe. Catena 2006, 66, 145-154. [CrossRef]

2. Vandenberghe, J. The fluvial cycle at cold-warm-cold transitions in lowland regions: A refinement of theory. Geomorphology 2008, 98, 275-284. [CrossRef]

3. Berger, J.F.; Delhon, C.; Magnin, F.; Bonté, S.; Peyric, D.; Thiébault, S.; Guilbert, R.; Beeching, A. A fluvial record of the mid-Holocene rapid climate changes in the middle Rhone valley (Espeluche-Lalo, France) and of their impact on Late Mesolithic and Early Neolithic societies. Quat. Sci. Rev. 2016, 136, 66-84. [CrossRef]

4. Kolb, T.; Fuchs, M.; Zöller, L. Deciphering fluvial landscape evolution by luminescence dating of river terrace formation: A case study from Northern Bavaria, Germany. Zeitschrift für Geomorphologie 2016, 60, $29-48$. [CrossRef]

5. von Suchodoletz, H.; Menz, M.; Kühn, P.; Sukhishvili, L.; Faust, D. Fluvial sediments of the Algeti River in southeastern Georgia-An archive of Late Quaternary landscape activity and stability in the Transcaucasian region. Catena 2015, 130, 95-107. [CrossRef]

6. von Suchodoletz, H.; Gärtner, A.; Zielhofer, C.; Faust, D. Eemian and post-Eemian fluvial dynamics in the Lesser Caucasus. Quat. Sci. Rev. 2018, 191, 189-203. [CrossRef]

7. von Suchodoletz, H.; Zielhofer, C.; Hoth, S.; Umlauft, J.; Schneider, B.; Zeeden, C.; Sukhishvili, L.; Faust, D. North Atlantic influence on Holocene flooding in the southern Greater Caucasus. Holocene 2018, 28, 609-620. [CrossRef] 
8. Notebaert, B.; Broothaerts, N.; Verstraeten, G. Evidence of anthropogenic tipping points in fluvial dynamics in Europe. Glob. Planet Chang. 2018, 164, 27-38. [CrossRef]

9. von Suchodoletz, H.; Faust, D. Late Quaternary fluvial dynamics and landscape evolution at the lower Shulaveris Ghele River (southern Caucasus). Quat. Res. 2018, 89, 254-269. [CrossRef]

10. Avşin, N.; Vandenberghe, J.; van Balen, R.; Kıyak, N.G.; Öztürk, T. Tectonic and climatic controls on Quaternary fluvial processes and river terrace formation in a Mediterranean setting, the Göksu River, southern Turkey. Quat. Res. 2019, 91, 533-547.

11. Lauer, T.; Weiss, M.; Bernhardt, W.; Heinrich, S.; Rappsilber, I.; Stahlschmidt, M.C.; von Suchodoletz, H.; Wansa, S. The Middle Pleistocene fluvial sequence at Uichteritz, central Germany: Chronological framework, paleoenvironmental history and evidence for human presence during MIS 11. Geomorphology 2020, 354, 107016. [CrossRef]

12. Bridgland, D.; Westaway, R. Climatically controlled river terrace staircases: A worldwide Quaternary phenomenon. Geomorphology 2008, 98, 285-315. [CrossRef]

13. Erkens, G.; Dambeck, R.; Volleberg, K.P.; Bouman, M.T.; Bos, J.A.; Cohen, K.M.; Wallinga, J.; Hoek, W.Z. Fluvial terrace formation in the northern Upper Rhine Graben during the last 20,000 years as a result of allogenic controls and autogenic evolution. Geomorphology 2009, 103, 476-495. [CrossRef]

14. Faust, D.; Wolf, D. Interpreting drivers of change in fluvial archives of the Western Mediterranean-A critical view. Earth-Sci. Rev. 2017, 174, 53-83. [CrossRef]

15. Pravalie, R. Drylands extent and environmental issues. A global approach. Earth Sci. Rev. 2016, 161, $259-278$. [CrossRef]

16. Weldeab, S.; Menke, V.; Schmiedl, G. The pace of East African monsoon evolution during the Holocene. Geophys. Res. Lett. 2014, 41, 1724-1732. [CrossRef]

17. Groucutt, H.S.; Petraglia, M.D. The prehistory of the Arabian Peninsula: Deserts, dispersals, and demography. Evol. Anthropol. 2012, 21, 113-125. [CrossRef]

18. Bull, W.B. Tectonic Geomorphology of Mountains; Blackwell Publishing: Oxford, UK, 2007.

19. Walker, R.T.; Fattahi, M. A framework of Holocene and Late Pleistocene environmental change in eastern Iran inferred from the dating of periods of alluvial fan abandonment, river terracing, and lake deposition. Quat. Sci. Rev. 2011, 30, 1256-1271. [CrossRef]

20. Harvey, A.M. Differential effects of base-level, tectonic setting and climatic change on Quaternary alluvial fans in the northern Great Basin, Nevada, USA. In Alluvial Fans: Geomorphology, Sedimentology, Dynamics; Harvey, A.M., Mather, A.E., Stokes, M., Eds.; Geological Society of London: London, UK, 2005; Volume 251, pp. 117-131.

21. Frostick, L.E.; Reid, I. Climatic versus tectonic control of fan sequences-Lessons from the Dead Sea, Israel. J. Geol. Soc. 1989, 146, 527-538. [CrossRef]

22. Nemec, W.; Postma, G. Quaternary alluvial fans in southwestern Crete: Sedimentation processes and geomorphic evolution. Sp. Publ. Int. 1993, 17, 235-276.

23. Dorn, R.I. The role of climatic change in alluvial fan development. In Geomorphology of Desert Environments, 2nd ed.; Parsons, A.J., Abrahams, A.D., Eds.; Springer: Berlin/Heidelberg, Germany, 2009; pp. 723-742.

24. Fuchs, M.; Reverman, R.; Owen, L.A.; Frankel, K.L. Reconstructing the timing of flash floods using 10Be surface exposure dating at Leidy Creek alluvial fan and valley, White Mountains, California-Nevada, USA. Quat. Res. 2015, 83, 178-186. [CrossRef]

25. Schmidt, A.; Quigley, M.; Fattahi, M.; Azizi, G.; Maghsoudi, M.; Fazeli, H. Holocene settlement shifts and palaeoenvironments on the Central Iranian Plateau: Investigating linked systems. Holocene 2011, 21, 583-595. [CrossRef]

26. Fattahi, M.; Walker, R.; Talebian, M.; Sloan, R.A.; Rasheedi, A. Late Quaternary active faulting and landscape evolution in relation to the Gowk Fault in the South Golbaf Basin, S.E. Iran. Geomorphology 2014, 204, 334-343. [CrossRef]

27. Fattahi, M.; Walker, R. Optical dating of Holocene lake bed sediments of the Nimbluk Plain, Khorasan, Northeast Iran: Implications for the climate change and palaeoenvironment. J. Earth Space Phys. 2016, 41, 1-12.

28. Hamzeh, M.A.; Mahmudy-Gharaie, M.H.; Alizadeh-Lahijani, H.; Moussavi-Harami, R.; Djamali, M.; Naderi-Beni, A. Paleolimnology of Lake Hamoun (E Iran): Implications for past climate changes and possible impacts on human settlements. Palaios 2016, 31, 616-629. [CrossRef] 
29. Vaezi, A.; Ghazban, F.; Tavakoli, V.; Routh, J.; Naderi Beni, A.; Bianchi, T.S.; Curtis, J.H.; Kylin, H. A Late Pleistocene-Holocene multi-proxy record of climate variability in the Jazmurian playa, southeastern Iran. Palaeogeogr. Palaeocl. 2019, 514, 754-767. [CrossRef]

30. Karimi, A.; Khademi, H.; Kehl, M.; Jalalian, A. Distribution, lithology and provenance of peridesert loess deposits in northeastern Iran. Geoderma 2009, 148, 241-250. [CrossRef]

31. Karimi, A.; Frechen, M.; Khademi, H.; Kehl, M.; Jalalian, A. Chronostratigraphy of loess deposits in northeast Iran. Quat. Int. 2011, 234, 124-132. [CrossRef]

32. Lauer, T.; Frechen, M.; Vlaminck, S.; Kehl, M.; Lehndorff, E.; Shahriari, A.; Khormali, A. Luminescence-chronology of the loess palaeosol sequence Toshan, Northern Iran-A highly resolved climate archive for the last glacial-interglacial cycle. Quat. Int. 2017, 429, 3-12. [CrossRef]

33. Lauer, T.; Vlaminck, S.; Frechen, M.; Rolf, C.; Kehl, M.; Sharifi, J.; Lehndorff, E.; Khormali, F. The Agh Band loess-paleosol sequence-A terrestrial archive for climatic shifts during the last and penultimate glacial-interglacial cycles in a semiarid region in northern Iran. Quat. Int. 2017, 429, 13-30. [CrossRef]

34. Vlaminck, S.; Kehl, M.; Lauer, T.; Shahriari, A.; Sharifi, J.; Eckmeier, E.; Lehndorff, E.; Khormali, F.; Frechen, M. Loess-soil sequence at Toshan (Northern Iran): Insights into late Pleistocene climate change. Quat. Int. 2016, 399, 122-135. [CrossRef]

35. Vlaminck, S.; Kehl, M.; Rolf, C.; Franz, S.O.; Lauer, T.; Lehndorff, E.; Frechen, M.; Khormali, F. Late Pleistocene dust dynamics and pedogenesis in Southern Eurasia-Detailed insights from the loess profile Toshan (NE Iran). Quat. Sci. Rev. 2018, 180, 75-95. [CrossRef]

36. Shabanian, E.; Bellier, O.; Abassi, M.R.; Siame, L.; Farbod, Y. Plio-Quaternary stress states in NE Iran: Kopeh Dagh and Allah Dagh-Binalud mountain ranges. Tectonophysics 2010, 480, 280-304. [CrossRef]

37. Shabanian, E.; Siame, L.; Bellier, O.; Benedetti, L.; Abbasi, M.R. Quaternary slip rates along the northeastern boundary of the Arabia-Eurasia collision zone (Kopeh Dagh Mountains, Northeast Iran). Geophys. J. Int. 2009, 178, 1055-1077. [CrossRef]

38. Hollingsworth, J.; Fattahi, M.; Walker, R.; Talebian, M.; Bahroudi, A.; Bolourchi, M.J.; Jackson, J.; Copley, A. Oroclinal bending, distributed thrust and strike-slip faulting, and the accommodation of Arabia-Eurasia convergence in NE Iran since the Oligocene. Geophys. J. Int. 2010, 181, 1214-1246. [CrossRef]

39. Shumilovskikh, L.S.; Hopper, K.; Djamali, M.; Ponel, P.; Demory, F.; Rostek, F.; Tachikawa, K.; Bittmann, F.; Golyeva, A.; Guibal, F.; et al. Landscape evolution and agro-sylvo-pastoral activities on the Gorgan Plain (NE Iran) in the last 6000 years. Holocene 2016, 26, 1-16. [CrossRef]

40. Shabanian, E.; Bellier, O.; Siame, L.; Abbassi, M.R.; Bourlès, D.; Braucher, R.; Farbod, Y. The Binalud Mountains: A key piece for the geodynamic puzzle of NE Iran. Tectonics 2012, 31, TC6003. [CrossRef]

41. Alijani, B.; Herman, J.R. Synoptic climatology of precipitation in Iran. Ann. Assoc. Am. Geogr. 1985, 75, 404-416. [CrossRef]

42. Noroozi, J.; Talebi, A.; Doostmohammadi, M.; Manafzadeh, S.; Asgarpour, Z.; Schneeweiss, G.M. Endemic diversity and distribution of the Iranian vascular flora across phytogeographical regions, biodiversity hotspots and areas of endemism. Sci. Rep. 2019, 9, 12991. [CrossRef] [PubMed]

43. Fattahi, M. OSL dating of the Miam Qanat (KĀRIZ) system in NE Iran. J. Archaeol. Sci. 2015, 59, 54-63. [CrossRef]

44. Rezai, M.H.; Soleymani, S.; Ahmadi, K. Bishiklik petroglyphs in Neyshabour county, northeastern Iran. Int. J. Archaeol. 2016, 4, 11-16. [CrossRef]

45. Rezaei, M.H.; Basafa, H. The impact of geological processes on the location of Shahrake Firouzeh, a prehistoric site from NE Iran. Anc. Asia 2019, 10, 1-8. [CrossRef]

46. Ministry of Mines and Metals, Geological Survey of Iran. Geological Quadrangle Map of Iran 1:250.000, No. 4-k Sheet Mashhad; Ministry of Mines and Metals, Geological Survey of Iran: Tehran, Iran, 1986.

47. Mohseni, N.; Hossseinzadeh, S.R.; Sepehr, A.; Golzarian, M.R.; Shabani, F. Variations in spatial patterns of soil-vegetation properties and the emergence of multiple resilience thresholds within different debris flow fan positions. Geomorphology 2017, 290, 365-375. [CrossRef]

48. Geological Survey and Mineral Exploration of Iran. Geological map of Iran 1:25,000 Series. Sheet 7862 III NW Kharve; Northeast Regional Geology Centre: Mashhad, Iran, 2015.

49. Fattahi, M.; Walker, R.T.; Khatib, M.M.; Dolati, A.; Bahroudi, A. Slip-rate estimate and past earthquakes on the Doruneh fault, eastern Iran. Geophys. J. Int. 2007, 168, 691-709. [CrossRef] 
50. Buylaert, J.-P.; Jain, M.; Murray, A.S.; Thomsen, K.J.; Thiel, C.; Sohbati, R. A robust feldspar luminescence dating method for Middle and Late Pleistocene sediments. Boreas 2012, 41, 435-451. [CrossRef]

51. Gibbard, P.L.; Lewin, J. River incision and terrace formation in the Late Cenozoic of Europe. Tectonophysics 2009, 474, 41-55. [CrossRef]

52. Al-Farraj, A.; Harvey, A.M. Morphometry and depositional style of Late Pleistocene alluvial fans: Wadi Al-Bih, northern UAE and Oman. In Alluvial fans: Geomorphology, Sedimentology, Dynamics; Harvey, A.M., Mather, A.E., Stokes, M., Eds.; Geological Society of London: London, UK, 2005; Volume 251, pp. 85-94.

53. Lewin, J.; Macklin, M.G. Preservation potential for Late Quaternary river alluvium. J. Quat. Sci. 2003, 18, 107-120. [CrossRef]

54. Fryirs, K.; Brierley, G.J. Antecedent controls on river character and behaviour in partly confined valley settings: Upper Hunter catchment, NSW, Australia. Geomorphology 2010, 117, 106-120. [CrossRef]

55. Yanites, B.J.; Tucker, G.E.; Mueller, K.J.; Chen, Y.G. How rivers react to large earthquakes: Evidence from central Taiwan. Geology 2010, 38, 639-642. [CrossRef]

56. Beaty, C.B. Great big boulders I have known. Geology 1989, 17, 349-352. [CrossRef]

57. Berger, A.; Loutre, M.F. Insolation values for the climate of the last 10 million years. Quat. Sci. Rev. 1991, 10, 297-317. [CrossRef]

58. Vandenberghe, J.; French, H.M.; Gorbunov, A.; Marchenko, S.; Velichko, A.A.; Jin, H.; Cui, Z.; Zhang, T.; Wan, X. The Last Permafrost Maximum (LPM) map of the Northern Hemisphere: Permafrost extent and mean annual air temperatures, 25-17 ka BP. Boreas 2014, 43, 652-666. [CrossRef]

59. Lisiecki, L.E.; Raymo, M.E. A Pliocene-Pleistocene stack of 57 globally distributed benthic $\delta 180$ records. Paleoceanography 2005, 20, PA1003. [CrossRef]

60. Rasmussen, S.O.; Andersen, K.K.; Svensson, A.; Steffensen, J.P.; Vinther, B.M.; Clausen, H.B.; Siggaard-Andersen, M.L.; Johnsen, S.J.; Larsen, L.B.; Dahl-Jensen, D.; et al. A new Greenland ice core chronology for the last glacial termination. J. Geophys. Res. 2006, 111. [CrossRef]

61. Lioubimtseva, E.; Cole, R.; Adams, J.M.; Kapustin, G. Impacts of climate and land-cover changes in arid lands of Central Asia. J. Arid Environ. 2005, 62, 285-308. [CrossRef]

62. Amiraslani, F.; Dragovich, D. Combating desertification in Iran over the last 50 years: An overview of changing approaches. J. Environ. Manag. 2011, 92, 1-13. [CrossRef] [PubMed]

63. Fletcher, W.; Faust, D.; Zielhofer, C. Fragile landscape systems. Catena 2013, 103, 1-2. [CrossRef]

64. Collins, P.E.F.; Rust, D.J.; Bayraktutan, M.S.; Turner, S.D. Fluvial stratigraphy and palaeoenvironments in the Pasinler Basin, eastern Turkey. Quat. Int. 2005, 140, 121-134. [CrossRef]

65. DeVecchio, D.E.; Heermance, R.V.; Fuchs, M.; Owen, L.A. Climate-controlled landscape evolution in the Western Transverse Ranges, California: Insights from Quaternary geochronology of the Saugus Formation and strath terrace flights. Lithosphere 2012, 4, 110-130. [CrossRef]

Publisher's Note: MDPI stays neutral with regard to jurisdictional claims in published maps and institutional affiliations.

(C) 2020 by the authors. Licensee MDPI, Basel, Switzerland. This article is an open access article distributed under the terms and conditions of the Creative Commons Attribution (CC BY) license (http://creativecommons.org/licenses/by/4.0/). 